\title{
Current Research and Development Status of Corrosion Behavior of Automotive Materials in Biofuels
}

\author{
Aamir Shehzad ${ }^{1}$, Arslan Ahmed ${ }^{1}$, Moinuddin Mohammed Quazi ${ }^{2}$, Muhammad Jamshaid ${ }^{3} \mathbb{D}$, \\ S. M. Ashrafur Rahman ${ }^{4, *}$, Masjuki Haji Hassan ${ }^{5}$ and Hafiz Muhammad Asif Javed ${ }^{6}$
}

1 Department of Mechanical Engineering, COMSATS University Islamabad, Sahiwal Campus 57000, Pakistan; aamir.shehzad@cuisahiwal.edu.pk (A.S.); arslanahmad@cuisahiwal.edu.pk (A.A.)

2 Faculty of Mechanical and Automotive Engineering Technology, Universiti Malaysia Pahang, Pekan 26600, Pahang, Malaysia; moinuddin@ump.edu.my

3 Department of Mechanical Engineering, Bahauddin Zakariya University, Multan 60000, Pakistan; muhammad.jamshaid@bzu.edu.pk

4 Biofuel Engine Research Facility, Queensland University of Technology, Brisbane, QLD 4000, Australia

5 Department of Mechanical Engineering, Faculty of Engineering, International Islamic University Malaysia (IIUM), Jalan Gombak, Kuala Lumpur 53100, Malaysia; masjuki@iium.edu.my

6 Department of Physics, University of Agriculture Faisalabad, Faisalabad 38000, Pakistan; majavedphy@yahoo.com

* Correspondence: s2.rahman@qut.edu.au

check for updates

Citation: Shehzad, A.; Ahmed, A.; Quazi, M.M.; Jamshaid, M.; Ashrafur Rahman, S.M.; Hassan, M.H.; Javed, H.M.A. Current Research and Development Status of Corrosion Behavior of Automotive Materials in Biofuels. Energies 2021, 14, 1440. https://doi.org/10.3390/en14051440

Academic Editor: Constantine D. Rakopoulos

Received: 30 November 2020 Accepted: 22 February 2021

Published: 6 March 2021

Publisher's Note: MDPI stays neutral with regard to jurisdictional claims in published maps and institutional affiliations.

Copyright: (c) 2021 by the authors. Licensee MDPI, Basel, Switzerland. This article is an open access article distributed under the terms and conditions of the Creative Commons Attribution (CC BY) license (https:/ / creativecommons.org/licenses/by/ $4.0 /)$.

\begin{abstract}
The world's need for energy is increasing with the passage of time and the substantial energy demand of the world is met by fossil fuels. Biodiesel has been considered as a replacement for fossil fuels in automotive engines. Biodiesels are advantageous because they provide energy security, they are nontoxic, renewable, economical, and biodegradable and clean sources of energy. However, there are certain disadvantages of biodiesels, including their corrosive, hygroscopic and oxidative natures. This paper provides a review of automotive materials when coming into contact with biodiesel blended fuel in terms of corrosion. Biodiesels have generally been proved to be corrosive, therefore it is important to understand the limits and extents of corrosion on different materials. Methods generally used to find and calculate corrosion have also been discussed in this paper. The reasons for the occurrence of corrosion and the subsequent problems because of corrosion have been presented. Biodiesel production can be carried out by different feedstocks and the studies which have been carried out on these biodiesels have been reviewed in this paper. A certain number of compounds form on the surface of materials because of corrosion and the mechanism behind the formation of these compounds along with the characterization techniques generally used is reviewed.
\end{abstract}

Keywords: corrosion; biodiesel; automotive materials; green fuels; corrosion test methods

\section{Introduction}

In biodiesel, the term "bio" implies that it is renewable as compared with petroleum fuels, and "diesel" represents that it has the potential to be used in diesel cycle motors [1]. Biodiesel is composed of unsaturated and saturated ester components, because of which it is considered to be less stable [2] and sensitive to light [3], temperature and metal ions. It can be obtained from animal fat, used cooking oil and vegetable oil with the help of methanol and ethanol [4]. The common sources of biofuels are animal fats and vegetables [5]. The common feedstock used for biodiesel production includes palm oil [6], sunflower oil [7], rapeseed oil [8], canola oil [9], soybean oil [10] and corn oil [11]. Another source of biodiesel production is waste chicken fat oil [12]. A transesterification process is applied to vegetable oils to produce biodiesel [13]. Some of the properties of both diesel and biodiesel are similar; however, they differ from each other because of chemical variations. Petroleum diesel has hundreds of compounds [14] that boil at different temperatures, while on the other hand biodiesel has only a few compounds, some of which are esters of long chain 
alkyls. Biodiesel has wastes that have resulted from the transesterification reactions of methanol, mono- and diglycerides, triglyceride intermediates and fatty acid derivatives other than the main constituents [15].

The world's need for energy is increasing over time because of increasing population and technological development [16]. Fossil fuels are meeting the substantial energy demand of the world, but are expensive [17]. The large production of fossil fuels is leading towards their depletion, which is why the world is going to suffer a huge energy crisis [18]. The extensive use of fossil fuels is leading to global warming and if not controlled, it can raise the temperature of the earth [19]. In addition to this, petroleum products obtained from fossil fuels are polluting the environment [20]. Thus, there is a need for an alternate source of energy. The importance of biodiesel has increased because of its ability to be used as an alternative fuel [21]. Moreover, biofuels are attractive because of their advantages such as being renewable [22], biodegradable [23], economical [24] and nontoxic [25]. Biodiesel can provide energy security to the world whilst having independence from fossil fuels [26], it can reduce emissions and it is a clean source of energy [27], it can be used directly or as a blend in diesel engines [28], it has a higher cetane number [29] and flash point [30] and additionally it showed improved combustion [31] and lubricity [32]. There are certain disadvantages associated with biodiesel as well. Such as its corrosive nature [33], it is more hygroscopic [34] and provides a slightly lower engine performance [35]. Furthermore, the fuel consumption of the engine increases when biodiesel is used [36], and the wear rate of parts in biodiesel is slightly increased [37]. Biodiesel is less volatile [38] and has poor properties in low temperatures [39].

Biofuel usage in the transport sector has been started as a replacement for gasoline [40]. Biodiesel is gaining importance because of its property of direct usage in engines or as a blending component in engines. Different countries of the world have started using it as a blend with petroleum diesel [41]. Research has shown that 30\% of ethanol with biodiesel can give effective results when added to diesel fuel. Additionally, it was recommended that $10 \%$ ethanol and $20 \%$ biodiesel can give better engine performance and the fewest emissions [42].

The biofuels which have been used in engines include palm oil [43], soybean oil [44], rapeseed oil [45], sunflower oil [46], olive oil [47], castor oil [48], jatropha curcas oil [49], pongamia pinnata oil [50], linseed oil [51] and milkweed seed oil [52], etc. Different parts of the engine are made from different materials. Some of the most common parts of the engines include exhaust system, piston assembly, fuel pump, fuel filter, fuel fed-up, fuel tank and fuel injection cylinder; the most common materials which are used in the manufacture of these parts include steel, aluminum, copper, plastic, rubber and ceramic fiber [53]. Engine parts including piston rings, pistons, bearings, filters, fuel injector, fuel liners, gaskets and fuel pump come in contact with the fuel [54]. Among these parts, copper-based alloys become most affected by the fuel [55]. The use of biofuels has some favorable effects on the material of the engine [56]. Biofuels have better lubricity at room temperature and by increasing the concentration of biofuel, deformation of worn surface decreases [37].

In addition to the introduction and pros and cons of biodiesel, this review has described the corrosion studies carried out on biodiesels obtained from feedstocks of different origins on engine materials. Furthermore, methods used to assess corrosion have been discussed in this paper. Other than that, the reasons and problems of corrosion are elaborated in this paper. Additionally, the characterization techniques along with the findings in corrosion studies and the mechanisms of products obtained after the corrosion on the materials have been discussed in this paper.

\section{Methods to Find Corrosion}

There are two methods that have been adopted by researchers to find the corrosion of materials in contact with biodiesel. 


\subsection{Immersion Test Method}

The process used is according to the ASTM G1 standard and it starts with the cutting of materials and inserting a hole in the desired dimensions. This hole is used to hang the material in the fuel. The materials are then ground and polished with the help of silicon carbide papers of different grades [57]. The samples are then washed with deionized water, dried and then dipped in acetone to degrease them [58]. The samples of each material are weighed initially on a digital balance with accuracy up to four decimal places. The samples are then immersed in the fuels for the specified duration, as shown in Figure 1. After removal, the materials are again washed and degreased by using acetone and then weighed again [41]. The difference in the weight of initial and final samples is further used in the calculation of the Corrosion Rate (CR) of materials according to the following formula [59].

$$
\mathrm{CR}=\left(8.76 \times 10^{4} \times \mathrm{W}\right) /(\mathrm{D} \times \mathrm{A} \times \mathrm{T}) \mathrm{mm} / \text { year }
$$

where:

$\mathrm{W}=$ weight loss $(\mathrm{g})$;

$\mathrm{D}=\operatorname{density}\left(\mathrm{g} / \mathrm{cm}^{3}\right)$;

$\mathrm{A}=$ cross sectional area $\left(\mathrm{cm}^{2}\right)$;

$\mathrm{T}=$ time (hours).

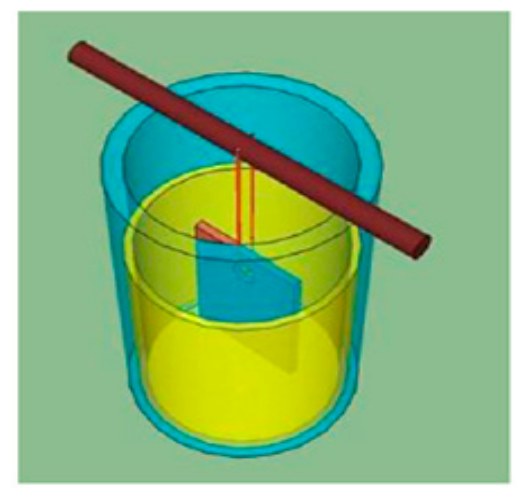

Figure 1. Schematic diagram for immersion test [1].

\subsection{Electro-Chemical Method}

This method uses the process of reduction and oxidation reactions. When corrosion occurs, the metal oxidizes and is gained or reduced in the solution. As this reaction involves the flow of electrons and current, it can be measured and calculated electronically [60].

The immersion test method is used generally by most researchers and the reason behind using this method is the efficiency of results [61], as the results obtained by this method use the actual scenario of contact between the biodiesel and the materials. Additionally, this testing is conducted for longer durations while the electrochemical method is carried out for only a few hours. Therefore, a longer duration allows the materials to settle properly in the fuel and results obtained by this method show linear relations. Additionally, this method helps in identifying products of corrosion obtained after the testing by using some characterization techniques. Moreover, the color of fuel and samples change in this method which helps in identifying the compositional changes of the fuel because of the corrosion. Hence, this method is preferred.

\section{Reasons and Problems of Corrosion of Materials in Biodiesel}

Biodiesel is believed to be corrosive and the reason behind this is its degradation, which is caused by the oxidation reactions taking place because of the absorption of moisture. The corrosiveness of biodiesel becomes more intense if it contains free fatty acids and free water. Likewise, the corrosiveness of biofuels can be increased by autooxidation [55]. The feedstock with which biodiesel is synthesized affects the corrosion of 
metals and this is because of the variation in the chemical composition of the biodiesel obtained from different feedstocks [62]. The rate of corrosion is promoted because the water condenses on the surface of materials [63].

The problem with biodiesel is its degradation when it is exposed to moisture and it oxidizes [64]. Metal oxides form because of biodiesel oxidation [1]. As the corrosiveness of biodiesel is higher, its wear rate becomes higher [55]. When the composition of the fuel changes or when an alternative fuel is used in engines, there comes the issues of material degradation and compatibility of the material with the fuel [42]. Biodiesel usage in the automotive sector is not particularly due to their corrosiveness and degradation properties [41]. Because of the absorption of moisture by the fuel or oxidation, the corrosion damage to the fuel system parts becomes more accelerated. Corrosion and wear of engine parts are increased by the oxidative behavior of the biodiesel [63].

\section{Corrosiveness of Biodiesels Obtained from Different Feedstock}

Different biodiesels have been used by different researchers for the corrosion rate calculation. The details of those studies are given below.

\subsection{Corrosion Studies on Palm Oil-Based Biodiesel}

Various researchers conducted studies to find the corrosion rate of automotive materials by using palm oil biodiesel. In their study, Thangavelu et al. investigated the corrosion of copper in Biodiesel-Diesel-Ethanol (BDE) fuel at Room Temperature (RT) and $50{ }^{\circ} \mathrm{C}$ by immersion tests. These tests were performed for $408 \mathrm{~h}$. The blends used were $45 \%$ biodiesel, 35\% diesel and 20\% bioethanol (B45D35E20). After $408 \mathrm{~h}$, at room temperature the corrosion rate was $0.277 \mathrm{mpy}$ and at $50^{\circ} \mathrm{C}$ it was $0.327 \mathrm{mpy}$. Pitting on the copper plate was more frequent at High Temperature (HT) than at RT. Additionally, Total Acid Number (TAN) values of the biodiesel were found to be increased at HT as compared to at RT [65]. Other researchers, Haseeb et al., conducted a similar study by using different blends of biodiesel for copper and leaded bronze by using the immersion test at room temperature for $2640 \mathrm{~h}$. The blends which were used were B0, B50 and B100. The immersion tests were performed at $60^{\circ} \mathrm{C}$ for $840 \mathrm{~h}$ for blends B0, B100 and B100 (oxidized). The corrosion rates of leaded bronze and copper in B100 were 0.018 and $0.042 \mathrm{mpy}$, respectively, at room temperature, while at $60^{\circ} \mathrm{C}$, the CRs of bronze and copper for B100 were 0.023 and $0.053 \mathrm{mpy}$, respectively. The corrosion rate for copper was higher than that of leaded bronze [55]. The following graphs in Figure 2 show the CR of copper and leaded bronze at RT and $60^{\circ} \mathrm{C}$.
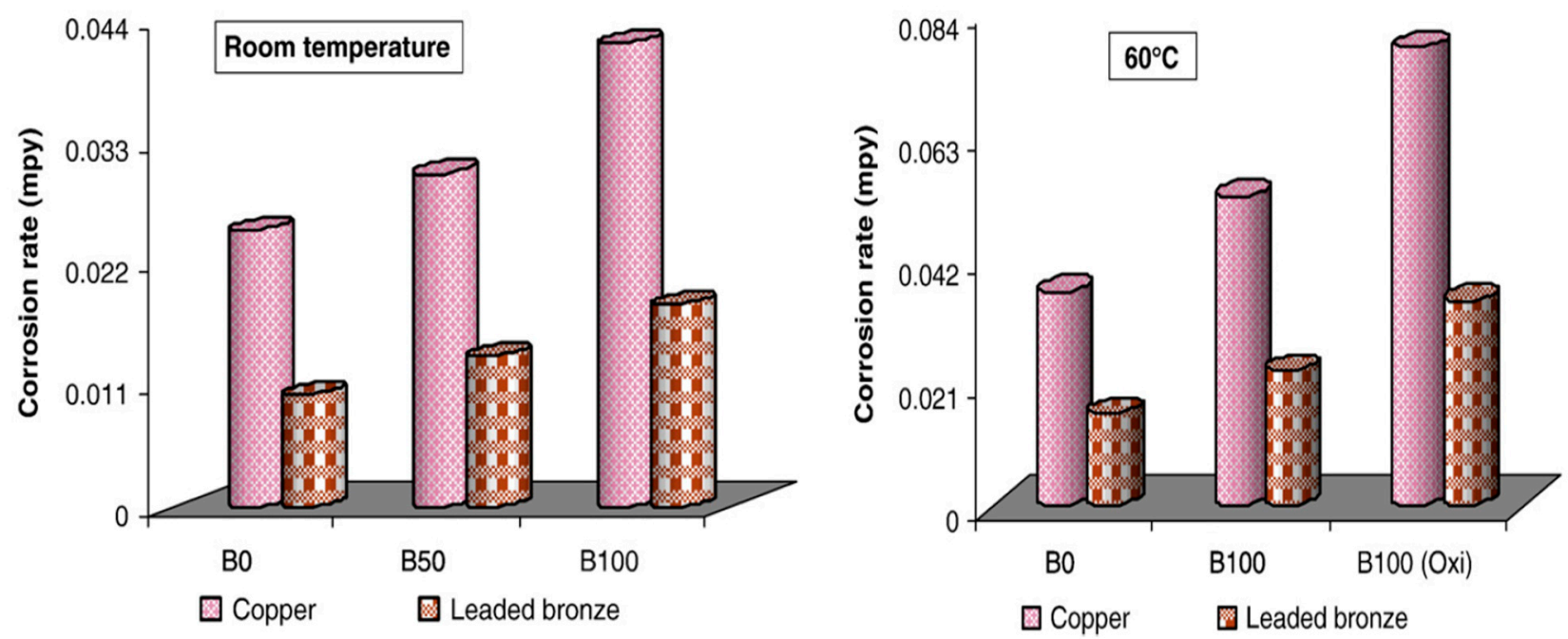

Figure 2. Corrosion Rates (CRs) of leaded bronze and copper at Room Temperature (RT) and $60{ }^{\circ} \mathrm{C}$ [55]. 
Another study was conducted by researchers for corrosion properties of Copper $(\mathrm{Cu})$, Brass (BS), Aluminum (Al) and Cast Iron (CI) when exposed to palm biodiesel and diesel. The tests performed were of immersion type for B0 and B100 blends. These tests were performed for $2880 \mathrm{~h}$ at room temperature. The CRs of $\mathrm{Cu}, \mathrm{BS}, \mathrm{Al}$ and $\mathrm{CI}$ were 0.38278 , $0.209898,0.173055$ and $0.112232 \mathrm{mpy}$, respectively. The TAN value of as-received biodiesel was $0.35 \mathrm{mg} \mathrm{KOH} / \mathrm{g}$. At the end of test, the TAN values of biodiesel increased to 2.57, 2.29, 1.68 and $1.69 \mathrm{mg} \mathrm{KOH} / \mathrm{g}$ in the case of $\mathrm{Cu}, \mathrm{BS}, \mathrm{Al}$ and $\mathrm{CI}$, respectively [64].

The same researcher performed another study on similar materials; however, this time it was not carried out at room temperature. This experiment was conducted at $80^{\circ} \mathrm{C}$ and the duration was reduced this time to $1200 \mathrm{~h}$. It was observed that the TAN number of the fuel was increased and it was higher than the limit according to ASTM D6751. It was observed that $\mathrm{Cu}$ and $\mathrm{Al}$ were more corrosive in biodiesel. At $1200 \mathrm{~h}$ and $80^{\circ} \mathrm{C}$, the corrosion rates for stainless steel (SS), $\mathrm{Al}$ and $\mathrm{Cu}$ in Palm biodiesel were 0.015, 0.202 and $0.586 \mathrm{mpy}$, respectively [33]. Figure 3 shows the corrosion rates of all materials.
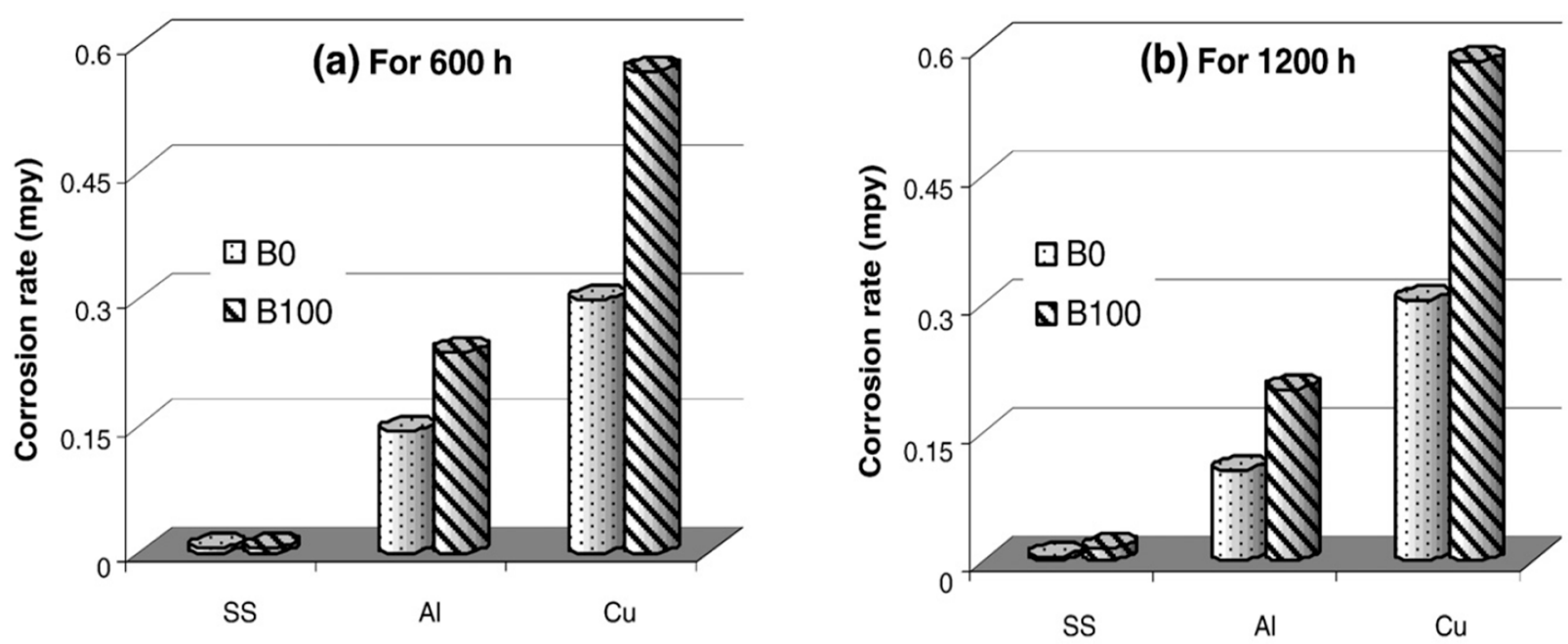

Figure 3. Corrosion rates of stainless steel (SS), aluminum (Al) and copper (Cu) [33].

From the above studies, it was observed that $\mathrm{Cu}$ showed higher corrosion rates followed by BS, $\mathrm{Al}$ and $\mathrm{CI}$. SS showed a minimum corrosion rate in palm biodiesel. Moreover, when temperature and duration of immersion were increased the corrosion rate was increased and the values for corrosion rate can be seen in Table 1 as well.

Some studies were made by researchers to assess the corrosion behavior on carbon steels. Thangavelu et al. studied corrosion behavior of BDE blends B0 and B20D70E10 with carbon steel by immersion tests. The tests were performed at RT and $60^{\circ} \mathrm{C}$ for 400 and $800 \mathrm{~h}$. CR of B20D70E10 at RT and at $60^{\circ} \mathrm{C}$ was more than the rate of B0 blend under the same conditions. At RT, it was $0.1817 \mathrm{mpy}$ and at $60^{\circ} \mathrm{C}$, it was $0.2612 \mathrm{mpy}$ for B20D70E10 and for $\mathrm{B} 0$ these values were $0.0523 \mathrm{mpy}$ and $0.115 \mathrm{mpy}$. It was noticed that the TAN in B20D70E10 was exceeded by the limit. Initially it was $0.25 \mathrm{mg} \mathrm{KOH} / \mathrm{g}$ for as-received biodiesel and after immersion it was increased to $1.15 \mathrm{mg} \mathrm{KOH} / \mathrm{g}$ at room temperature and $1.59 \mathrm{mg} \mathrm{KOH} / \mathrm{g}$ at $60^{\circ} \mathrm{C}$ [42]. The surface morphology of carbon steel is shown in Figure 4. 
Table 1. Summary of corrosion studies using palm oil-based biodiesel.

\begin{tabular}{|c|c|c|c|c|c|c|c|c|}
\hline Sr. No. & Test Type & Material & Biofuel Blends & Temperature & Time & Characterization & TAN (mg KOH/g) & Corrosion Rate \\
\hline \multirow[b]{2}{*}{1.} & \multirow{2}{*}{ Immersion Test } & \multirow{2}{*}{ Pure Copper } & \multirow{2}{*}{$\begin{array}{l}45 \% \text { biodiesel, 35\% diesel and } \\
20 \% \text { bioethanol (B45D35E20) }\end{array}$} & Room temperature & \multirow{2}{*}{$408 \mathrm{~h}$} & \multirow{2}{*}{ OM, FTIR } & \multirow{2}{*}{$\begin{array}{l}\text { Increased at high } \\
\text { temperature }\end{array}$} & 0.277 mpy [65] \\
\hline & & & & $50^{\circ} \mathrm{C}$ & & & & $0.327 \mathrm{mpy}$ \\
\hline \multirow{2}{*}{2.} & \multirow{2}{*}{ Immersion Test } & \multirow{2}{*}{$\begin{array}{l}\text { Copper, Leaded } \\
\text { Bronze }\end{array}$} & B0, B50, B100 & Room temperature & $2640 \mathrm{~h}$ & \multirow{2}{*}{$\begin{array}{l}\text { TAN analyzer, } \\
\text { FTIR, MOA }\end{array}$} & \multirow[t]{2}{*}{-} & $\begin{array}{c}0.018 \mathrm{mpy} \\
\text { (Bronze) and } 0.042 \\
\text { mpy (Copper) [55] }\end{array}$ \\
\hline & & & B0, B100, B100(oxidized) & $60^{\circ} \mathrm{C}$ & $840 \mathrm{~h}$ & & & $\begin{array}{c}0.023 \mathrm{mpy} \\
\text { (Bronze) and } 0.053 \\
\text { mpy (Copper) }\end{array}$ \\
\hline 3. & Immersion Test & $\begin{array}{c}\text { Copper, Brass, } \\
\text { Aluminum, Cast } \\
\text { Iron }\end{array}$ & B0, B100 & Room temperature & $2880 \mathrm{~h}$ & SEM/EDS, XRD & $\begin{array}{c}0.35 \text { (as-received), } \\
2.57 \text { (Copper), } 2.29 \\
\text { (Brass), } 1.68 \\
\text { (Aluminum), } 1.69 \\
\text { (Cast Iron) }\end{array}$ & $\begin{array}{c}0.38278 \mathrm{mpy} \\
\text { (Copper), } 0.209898 \\
\text { mpy (Brass), } \\
0.173055 \mathrm{mpy} \\
\text { (Aluminum) and } \\
0.112232 \mathrm{mpy} \\
\text { (Cast Iron) [64] }\end{array}$ \\
\hline 4. & Immersion Test & $\begin{array}{l}\text { Copper, Stainless } \\
\text { Steel, Aluminum }\end{array}$ & B0, B100 & $80^{\circ} \mathrm{C}$ & $1200 \mathrm{~h}$ & OM, SEM, EDS & $\begin{array}{l}\text { Increased to limit } \\
\text { according to } \\
\text { ASTM D6751 }\end{array}$ & $\begin{array}{c}0.015 \mathrm{mpy} \\
\text { (Stainless Steel), } \\
0.202 \mathrm{mpy} \\
\text { (Aluminum) and } \\
0.586 \mathrm{mpy} \\
\text { (Copper) [33] }\end{array}$ \\
\hline \multirow[t]{2}{*}{5.} & \multirow[t]{2}{*}{ Immersion Test } & \multirow[t]{2}{*}{ Carbon Steel } & \multirow[t]{2}{*}{$\begin{array}{c}\text { B0, } \\
\text { B20D70E10 }\end{array}$} & Room temperature & \multirow[t]{2}{*}{$\begin{array}{l}800 \mathrm{~h} \\
400 \mathrm{~h}\end{array}$} & \multirow[t]{2}{*}{ OM, FTIR } & \multirow{2}{*}{$\begin{array}{c}0.25 \text { (as-received) } \\
1.15 \text { (Room } \\
\text { temperature) } 1.59 \\
\left(60^{\circ} \mathrm{C}\right)\end{array}$} & $\begin{array}{c}0.1817 \mathrm{mpy} \\
\text { (B20D70E10) and } \\
0.0523 \text { (B0) [42] }\end{array}$ \\
\hline & & & & $60^{\circ} \mathrm{C}$ & & & & $\begin{array}{c}0.2612 \mathrm{mpy} \\
\text { (B20D70E10) and } \\
0.115 \mathrm{mpy}(\mathrm{B} 0)\end{array}$ \\
\hline 6. & Immersion Test & $\begin{array}{l}\text { Carbon Steel } \\
\text { ASTM } 1045\end{array}$ & - & $27^{\circ} \mathrm{C}, 50^{\circ} \mathrm{C}, 80^{\circ} \mathrm{C}$ & $\begin{array}{l}30,60,120 \\
\text { days }\end{array}$ & $\begin{array}{l}\text { SEM/EDS, XRD, } \\
\text { FTIR }\end{array}$ & $\begin{array}{l}\text { Increased with the } \\
\text { increase in } \\
\text { temperature and } \\
\text { time }\end{array}$ & $\begin{array}{l}\text { With the rise in } \\
\text { temperature and } \\
\text { exposure time the } \\
\text { CRs of Mild Steel } \\
\text { increased in both } \\
\text { fuels [66] }\end{array}$ \\
\hline
\end{tabular}


Table 1. Cont.

\begin{tabular}{|c|c|c|c|c|c|c|c|c|}
\hline Sr. No. & Test Type & Material & Biofuel Blends & Temperature & Time & Characterization & TAN (mg KOH/g) & Corrosion Rate \\
\hline 7. & Immersion Test & Mild Steel & B0, B50, B100 & $\begin{array}{c}\text { Room } \\
\text { temperature, } 50 \\
{ }^{\circ} \mathrm{C}, 80{ }^{\circ} \mathrm{C}\end{array}$ & $1200 \mathrm{~h}$ & $\begin{array}{c}\text { OM, SEM, EDS, } \\
\text { XRD }\end{array}$ & $\begin{array}{l}\text { Increased to limit } \\
\text { according to } \\
\text { ASTM D6751 }\end{array}$ & $\begin{array}{l}\text { At RT, the CR of } \\
\text { MS in biodiesel } \\
\text { and diesel was } \\
0.052 \mathrm{mpy} \text { and } \\
0.046 \mathrm{mpy} \text {, } \\
\text { respectively. } \\
\text { While at } 80^{\circ} \mathrm{C} \text { the } \\
\mathrm{CR} \text { was } 0.059 \mathrm{mpy} \\
\text { and } 0.05 \mathrm{mpy} \text {, } \\
\text { respectively [67] }\end{array}$ \\
\hline \multirow{2}{*}{8.} & \multirow{2}{*}{ Immersion Test } & \multirow{2}{*}{$\begin{array}{l}\text { Aluminum, } \\
\text { Magnesium }\end{array}$} & \multirow{2}{*}{ B100 } & \multirow{2}{*}{ Room temperature } & $720 \mathrm{~h}$ & \multirow{2}{*}{$\begin{array}{c}\text { SEM/EDS, XRD, } \\
\text { FTIR }\end{array}$} & \multirow{2}{*}{$\begin{array}{c}0.27 \text { (as-received) } \\
0.92 \text { (Aluminum) } \\
0.87 \text { (Magnesium) }\end{array}$} & $\begin{array}{c}0.1230 \text { mpy } \\
\text { (Aluminum) and } \\
3.0910 \text { mpy } \\
\text { (Magnesium) [68] }\end{array}$ \\
\hline & & & & & $1440 \mathrm{~h}$ & & & $\begin{array}{c}0.0527 \mathrm{mpy} \\
\text { (Aluminum) and } \\
2.6563 \mathrm{mpy} \\
\text { (Magnesium) }\end{array}$ \\
\hline 9. & Immersion Test & Copper, Mild Steel & - & Room temperature & 60 days & SEM/EDS, AFM & - & $\begin{array}{c}\text { CR of Copper was } \\
\text { decreased } \\
\text { effectively by } \\
\text { using } \\
\text { Benzotriazole than } \\
\text { that of Mild Steel. } \\
\text { In the presence of } \\
\text { Adenine, the CR } \\
\text { of Copper } \\
\text { decreased from } \\
0.7495 \text { to } 0.2512 \\
\mathrm{mg} / \mathrm{cm}^{2}[69]\end{array}$ \\
\hline
\end{tabular}




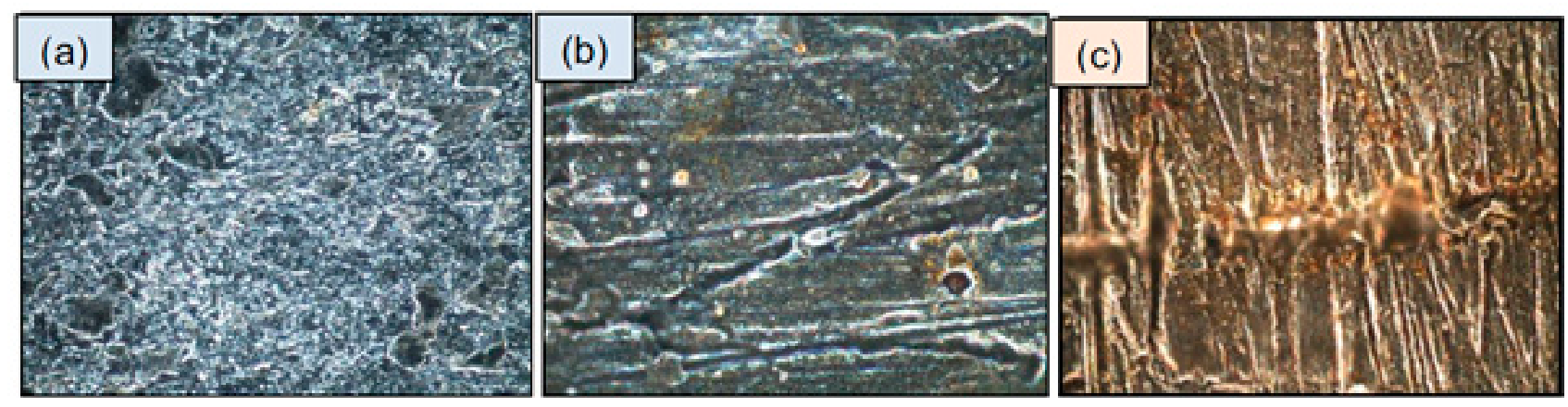

Figure 4. Surface morphology (a) B0 at RT; (b) B20D70E10 at RT; (c) B20D70E10 at $60{ }^{\circ} \mathrm{C}$ [42].

Another study was conducted by Jin et al. on ASTM 1045 MS for investigation of its corrosion behavior when immersed in palm biodiesel at 27, 50 and $80{ }^{\circ} \mathrm{C}$ for 30,60 and 120 days, and these results were then compared with the commercial diesel. With the rise in temperature and exposure time the CRs of MS increased in both fuels. It was observed that corrosion rates obtained with commercial diesel were lower than those of palm biodiesel. The TAN values of biodiesel and diesel increase with the increase in exposure time and temperature [66].

B0, B50 and B100 blends of MS were again investigated for corrosion behavior by Fazal et al. at room temperature, 50 and $80{ }^{\circ} \mathrm{C}$ by static immersion tests for $1200 \mathrm{~h}$. It was found that petroleum diesel is less corrosive than the biodiesel. At RT, CRs of MS in biodiesel and diesel were 0.052 and 0.046 mpy, respectively. At $80{ }^{\circ} \mathrm{C}$, the corrosion rates were 0.059 and 0.05 mpy, respectively. The water content was increased by increasing immersion temperature. Additionally, it was observed that the TAN of fuel was increased and it was higher than the limit according to ASTM D6751 [67].

Studies on carbon steels showed that CR increases by increasing the concentration of biodiesel in diesel for carbon steel and mild carbon steel. With the increase in temperature, the CR had increased for all carbon steels presented above. Additionally, it was noticed that the duration of immersion had affected CR and it was increased with the increase in duration. Petroleum diesel was found to be the least corrosive. TAN values of the biodiesel increased. The values of CR can be seen in Table 1 . It concludes that the values of CR are directly proportional to the duration of immersion, temperature and blend percentage.

Another work conducted by Chew et al. assessed the corrosion behavior of aluminum and Magnesium (Mg) for 720 and $1440 \mathrm{~h}$ by immersion test. The corrosion rates of $\mathrm{Al}$ were 0.1230 and $0.0527 \mathrm{mpy}$ at 720 and $1440 \mathrm{~h}$, respectively. Similarly, $\mathrm{Mg}$ showed rates of 3.0910 and 2.6563 mpy at 720 and $1440 \mathrm{~h}$, respectively. Mg exhibits higher corrosion rates as compared to $\mathrm{Al}$ was due to the higher reactivity of magnesium. It was noted that $\mathrm{Mg}$ was less noble as compared to $\mathrm{Mg}$ in galvanic series. The corrosion rates of both materials decreased with the increase in duration, as shown in Table 1 . The TAN values of both materials after exposure to biodiesel enhanced from $0.27 \mathrm{mg} \mathrm{KOH} / \mathrm{g}$ of as-received biodiesel to 0.87 and $0.92 \mathrm{mg} \mathrm{KOH} / \mathrm{g}$ of biodiesel in which $\mathrm{Mg}$ and $\mathrm{Al}$ were immersed, respectively [68]. Figure 5 shows the corrosion rates of both materials.

Summaries of these studies are shown in Table 1 below.

\subsection{Corrosion Studies on Jatropha Oil-Based Biodiesel}

There are a few studies on Jatropha oil-based biodiesels to assess corrosion rates of automotive materials. A study was completed by Dharma et al. where he used 50\% jatropha curcas and 50\% ceiba pentandra (J50C50) biodiesels to assess corrosion behavior of MS by static immersion tests at room temperature for 400 and $800 \mathrm{~h}$ for blends B0, B10, B20, B30, B40 and B50. The corrosion rates at all mixtures were higher at all blends at $400 \mathrm{~h}$ and these were $0.0018,0.0011,0.0198,0.0199,0.0222$ and $0.0289 \mathrm{~mm} /$ year for B0, B10, B20, 
B30, B40 and B50, respectively, as shown below in Table 2. The corrosion rate for B50 was 15 times higher than that of diesel fuel. It can be noticed that the weight loss is not linear with immersion time and it tends to slow down as the duration increases. Therefore, it can be noticed that for B20, B30 and B50, corrosion rates decreased at $800 \mathrm{~h}$ and were 0.01176 , 0.01546 and $0.02524 \mathrm{~mm} /$ year, respectively, as shown in Table 2. The acid value of the fuel was higher, although it was still in range as compared to ASTM D 6751 standards [41].

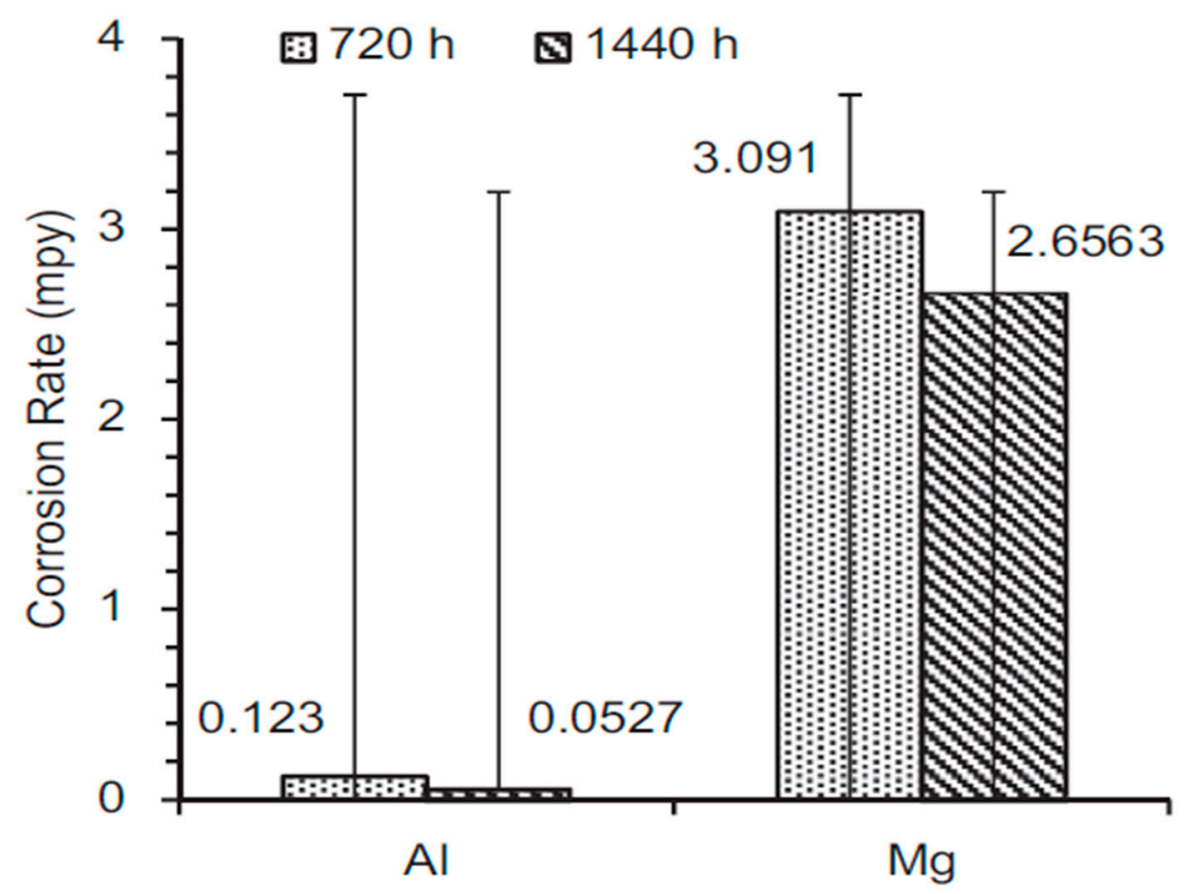

Figure 5. Corrosion rates of magnesium and aluminum at 720 and $1440 \mathrm{~h}$ [68].

Another study was conducted by Akhabue et al. on Al and MCS in Jatropha oil-based biodiesel by static immersion tests for blends B0, B50 and B100 at RT for 18 weeks (3 weeks interval). It was observed that in the case of MCS, there was an increase in CR up to the 12 th week. The CR of B50 remained same between the 12th and 15th weeks. However, it was reduced for B0 and B100 after the 12th week. At the end of the experiment, the CRs of MCS in B0, B50 and B100 were 0.0011, 0.0022 and 0.0026 mpy, respectively, as shown in Table 2 . In the case of $\mathrm{Al}, \mathrm{CRs}$ were found to be increased up until the 12th week. The maximum corrosion rates for B50 and B100 were obtained in the 15th week, reaching 0.0099 and 0.016 mpy, respectively, while for $\mathrm{B} 0$ the maximum value was obtained in the 12th week. However, there was a decreased CR for B0 in the 15th week. B50 showed a decrease in rate between the 9th and 12th weeks. The same CRs were found to be increased from the 12th week in $\mathrm{B} 50$ and $\mathrm{B} 100$. If compared, the corrosion rates of $\mathrm{Al}$ were lower than those of MCS under the same conditions as shown in Table 2. The TAN values of as-received biodiesel were 0.41 and $0.52 \mathrm{mg} \mathrm{KOH} / \mathrm{g}$ for B100 and B50, respectively, while after immersion these values were 3.53 and $1.54 \mathrm{mg} \mathrm{KOH} / \mathrm{g}$ for B100 and B50, respectively, in the case of MCS, and 2.81 and $1.51 \mathrm{mg} \mathrm{KOH} / \mathrm{g}$ for B100 and B50, respectively, in the case of $\mathrm{Al}$ [62]. 
Table 2. Summary of corrosion studies using jatropha oil-based biodiesel.

\begin{tabular}{|c|c|c|c|c|c|c|c|c|}
\hline Sr. No. & Test Type & Material & Biofuel Blends & Temperature & Time & Characterization & TAN (mg KOH/g) & Corrosion Rate \\
\hline 1. & Immersion Test & $\begin{array}{l}\text { Piston metal, } \\
\text { Piston liner }\end{array}$ & B100 & Room temperature & 300 days & - & $\begin{array}{l}0.38 \text { (as-received), } \\
19.54 \text { (piston liner), } \\
14.48 \text { (piston metal) }\end{array}$ & $\begin{array}{l}\text { Salvadora is the most } \\
\text { corrosive biodiesel } \\
\text { followed by jatropha } \\
\text { curcas, mahua and } \\
\text { karanja [70] }\end{array}$ \\
\hline 2. & Immersion Test & Mild Steel & $\begin{array}{c}\text { B0, B10, B20, B30, } \\
\text { B40, B50 }\end{array}$ & Room temperature & $400 \mathrm{~h}, 800 \mathrm{~h}$ & SEM & $\begin{array}{c}\text { Higher however in } \\
\text { range as compared } \\
\text { to ASTM D } 6751 \\
\text { standards }\end{array}$ & $\begin{array}{c}\text { CRs were higher at } 400 \\
\text { h and were 0.0018 (B0), } \\
0.0011(\mathrm{~B} 10), 0.0198 \\
\text { (B20), 0.0199 (B30), } \\
0.0222(\mathrm{~B} 40) \text { and } 0.0289 \\
\text { (B50) mm/year. For B20, } \\
\text { B30 and B50, CRs } \\
\text { decreased to 0.01176, } \\
0.01546 \text { and } 0.02524 \\
\mathrm{~mm} / \text { year at } 800 \mathrm{~h}[41]\end{array}$ \\
\hline 3. & Immersion Test & $\begin{array}{l}\text { Aluminum, Mild } \\
\text { Carbon Steel }\end{array}$ & B0, B50, B100 & Room temperature & $\begin{array}{l}18 \text { weeks } \\
\text { ( } 3 \text { weeks } \\
\text { interval) }\end{array}$ & - & $\begin{array}{c}0.41 \text { and } 0.52 \\
\text { (as-received B100 } \\
\text { and B50), } 3.53 \text { and } \\
1.54 \text { (MCS B100 and } \\
\text { B50), } 2.81 \text { and 1.51 } \\
\text { (A1 B100 and B50) }\end{array}$ & $\begin{array}{l}\text { The CRs of Aluminum } \\
\text { were lower than those } \\
\text { of MCS. The CRs of } \\
\text { MCS in B0, B50 and } \\
\text { B100 were } 0.0011,0.0022 \\
\text { and } 0.0026 \text { mpy, } \\
\text { respectively. The CRs of } \\
\text { Al in B50 and B100 were } \\
0.0099 \text { and } 0.016 \text { mpy in } \\
\text { the 15th week [62] }\end{array}$ \\
\hline
\end{tabular}


In another study, researchers used biodiesels of Indian origin (salvadora oleoides, madhuca indica, pongamia glabra and jatropha curcas) for the corrosion behavior of materials by static immersion method for 300 days at room temperature on piston metal and piston liner parts. In the case of piston liner, there were clear weight losses observed in all samples of biodiesel. Weight loss was slightly higher in the case of jatropha curcas biodiesel. In the case of piston metal, the corrosion in mahua and karanja oisl was comparable to that of corrosion in petro diesel, while in that of jatropha curcas was slightly higher. The weight loss in salvadora was 10 times higher than that obtained in jatropha curcas oil as shown in Table 2. The TAN values for salvadora oleoides, madhuca indica, pongamia glabra and jatropha curcas were $0.45,0.32,0.42$ and $0.38 \mathrm{mg} \mathrm{KOH} / g$, respectively, before immersion, while after immersion these values were $2.51,19.72,17.52$ and $19.54 \mathrm{mg} \mathrm{KOH} / \mathrm{g}$, respectively, for piston liner and 2.38, 11.3, 14.39 and $14.48 \mathrm{mg} \mathrm{KOH} / \mathrm{g}$, respectively, for piston metal [70].

Hence, it was clear from the above studies that jatropha biodiesel is also corrosive for automotive materials and the corrosiveness increases by increasing the concentration of biodiesel. However, it did not show any particular trend with the duration of immersion and in some cases the CR was decreased by increasing the duration. Furthermore, it was noticed that Al did not show any significant corrosion in this biodiesel and CR of MCS was higher as compared to Al as shown in Table 2. However, Jatropha biodiesel showed the same trends with the TAN values and these were increased by the use of biodiesel.

Summaries of these studies have been shown in Table 2 below.

\subsection{Corrosion Studies on Rapeseed Oil-Based Biodiesel}

Various researchers conducted studies to find the corrosion rate of automotive materials by using rapeseed oil-based biodiesel. A study was carried out by Sterpu et al. in which he investigated corrosion of Carbon Steel (CS) in corn, rapeseed and sunflower biodiesels by immersion tests at RT for $1176 \mathrm{~h}$. The CRs of CS in corn, rapeseed and sunflower biodiesel were $0.001164,0.000760$ and $0.000855 \mathrm{~mm} /$ year, respectively, as shown in a graph in Figure 6. Likewise, the TAN of biodiesel was increased [63].

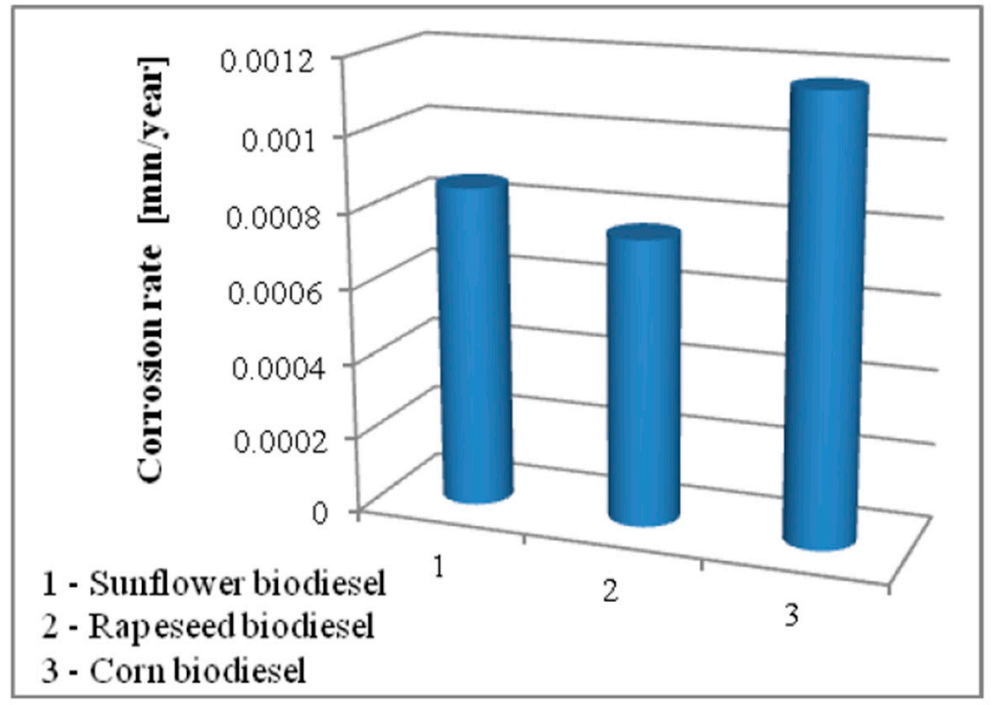

Figure 6. CRs of carbon steel in three different biodiesels [63].

In another work, $\mathrm{Hu}$ et al. used the B20 blend of rapeseed biodiesel to study the corrosion behaviors of SS, Al, MCS and $\mathrm{Cu}$ by immersion tests at $43^{\circ} \mathrm{C}$ for 2 months. The corrosion of $\mathrm{Al}$ and SS was much lower than the corrosion of MCS and $\mathrm{Cu}$ in biodiesel. The corrosion rates of $\mathrm{Cu}$ and MCS were 0.02334 and $0.01819 \mathrm{~mm} /$ year in biodiesel while 0.0037 and $0.0015 \mathrm{~mm} /$ year for diesel, respectively, as shown in Figure 7 [71]. 


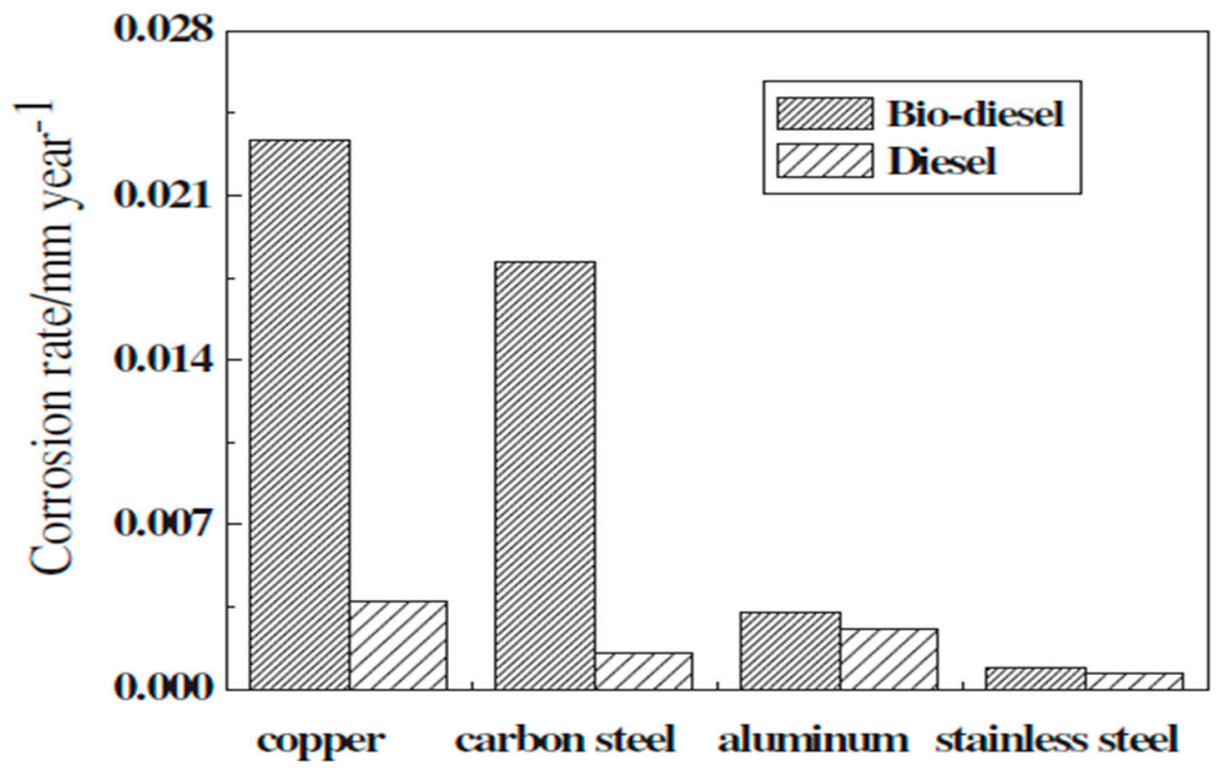

Figure 7. CRs of metals in diesel and biodiesel [71].

Additionally, B0, B50, B75 and B100 blends of rapeseed methyl ester with ultra-low sulfur diesel fuel were used by Norouzi et al. to study the corrosion of AW 6060 aluminum alloy and E-Cu57 copper by immersion tests $600 \mathrm{~h}$ at $80^{\circ} \mathrm{C}$. They observed that the increase in biodiesel concentration enhanced the corrosion of the biodiesel, as shown in Figure 8. Additionally, the increased temperature increased the corrosiveness of biodiesel. The TAN of biodiesel was initially $0.315 \mathrm{mg} \mathrm{KOH} / \mathrm{g}$ and after immersion, it was more than the limit according to ASTM D6751, which is $0.8 \mathrm{mg} \mathrm{KOH} / \mathrm{g}$ for biodiesel. The color of the biodiesel changed in both materials due to the change in the composition of the biodiesel [72].

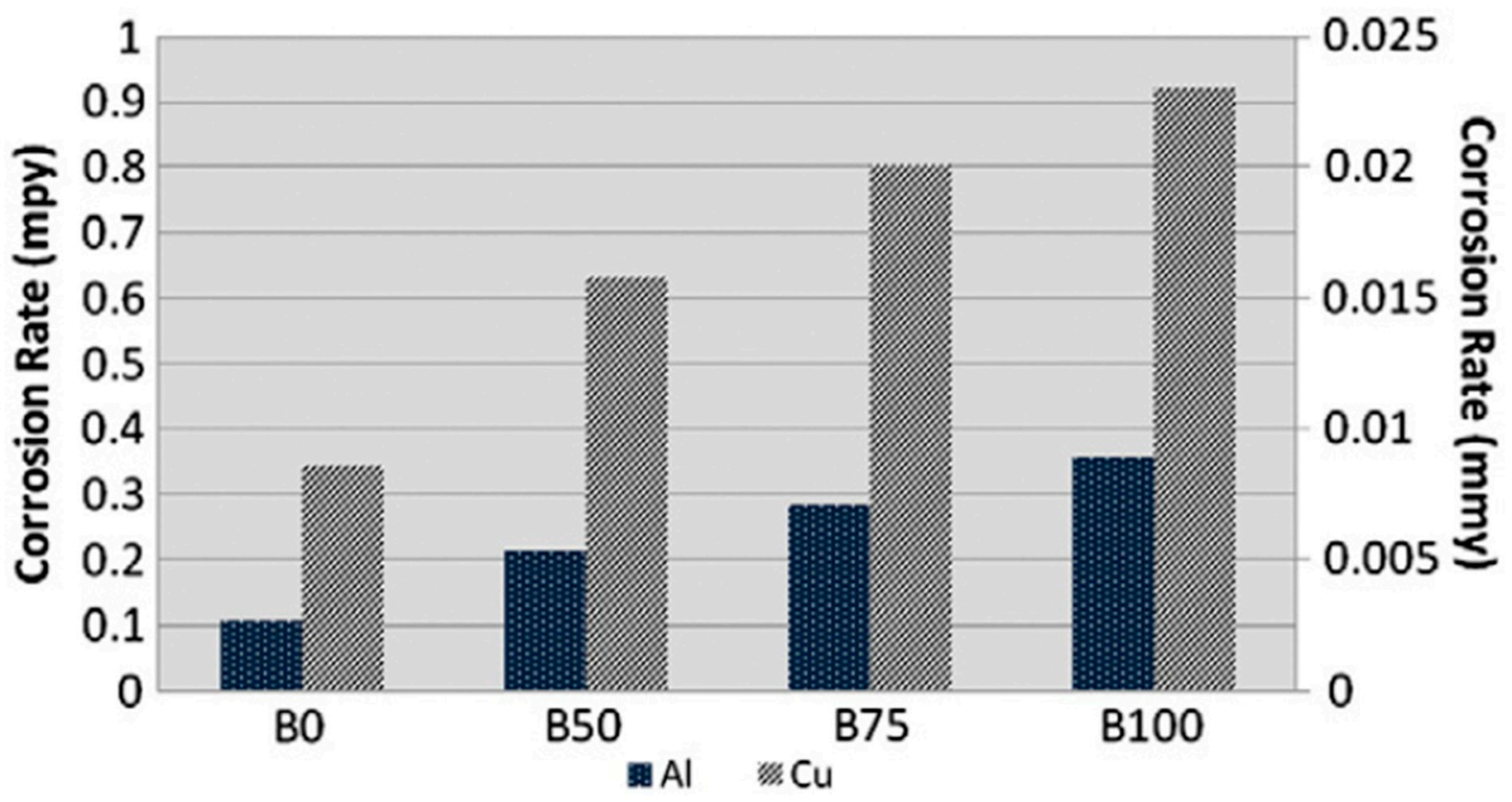

Figure 8. $\mathrm{CRs}$ of $\mathrm{Cu}$ and $\mathrm{Al}$ in fuel blends [72].

In the case of rapeseed biodiesel, it can be concluded that this biodiesel showed similar trends as compared to other biodiesels. The increased concentration of biodiesel 
and increased temperature increased the corrosion rates of metals, as shown in Table 3. Furthermore, TAN values of the biodiesel were found to be increased.

Summaries of these studies have been shown in Table 3 below.

\subsection{Corrosion Studies on Sunflower Oil-Based Biodiesel}

Some of the studies were conducted to find the corrosion rates of automotive materials by using sunflower oil-based biodiesels. In their study, Samuel et al. investigated corrosion properties of brass in B10, B20 and B40 blends of waste sunflower oil biodiesel (WSOB) by immersion tests at room temperature for 240,480, 720 and $960 \mathrm{~h}$. By increasing duration and the biodiesel fraction, the corrosion of the BS increased. The TAN of the as-received fuel was $0.297 \mathrm{mg} \mathrm{KOH} / \mathrm{g}$, which increased to $0.35,0.4,0.47,0.73$ and $1.95 \mathrm{mg} \mathrm{KOH} / \mathrm{g}$ for B0, B10, B20, B40 and B100 blends, respectively. This was because of the acid component variation [73]. A similar study on B0, B20 and B100 was performed by Cursaru et al. to assess corrosion rates of ferrous alloy, $\mathrm{Cu}$ and $\mathrm{Al}$ using the static immersion test at $\mathrm{RT}$ and $60{ }^{\circ} \mathrm{C}$ for $3000 \mathrm{~h}$. The corrosion rate of each metal increased by increasing the fraction of biodiesel in the blend. At room temperature, the corrosion rates of $\mathrm{Cu}, \mathrm{Al}$ and MCS were $0.323615,0.162201$ and 0.170124 mpy, respectively, as shown in Table 4 [74]. Similarly, at $60{ }^{\circ} \mathrm{C}$, these results were $0.640758,0.316292$ and $0.336845 \mathrm{mpy}$, respectively.

Another study was presented by Cursaru et al. and this time he used the electrochemical method for corrosion rate calculation and the materials used were changed to monel steel, stainless steel and mild steel. The biodiesel used in this study was in percentages of 1,5 and 10 for $3 \mathrm{~h}$ at $50{ }^{\circ} \mathrm{C}$. The TAN of as-received fuel was $0.12 \mathrm{mg} \mathrm{KOH} / \mathrm{g}$ which was increased to $0.18,0.2,0.21$ and $0.3 \mathrm{mg} \mathrm{KOH} / \mathrm{g}$ for B1, B5, B10 and B100 blends, respectively. The monel steel was the least corroded as compared to stainless steel and mild steel. The corrosion rate of monel steel was $0.000045 \mathrm{~mm}$ /year, stainless steel was $0.000421 \mathrm{~mm} /$ year and mild carbon steel was $0.000514 \mathrm{~mm} /$ year, as shown in Table 4 [75].

Additionally, the trends of sunflower biodiesel were similar in terms of corrosion rate to other biodiesels as the CRs of materials in it were increased by the increase in the concentration of biodiesel and duration. The corrosion rate of diesel was lower as compared to biodiesel. Furthermore, an increased temperature increased the corrosion, as shown below in Table 4 . TAN of the biodiesel was increased as well.

Summaries of these studies have been shown in Table 4 below.

\subsection{Corrosion Studies on Biodiesel Obtained from Different Feedstocks}

Many other studies to assess the corrosion rates of materials were presented by several researchers by using biodiesel obtained from the different feedstocks. Diaz-Ballote et al. used canola biodiesel to assess the corrosion rate of $\mathrm{Al}$ by an electrochemical technique. It was observed that the corrosion of $\mathrm{Al}$ can be used as an indicator to assess the purity of the biodiesel as Al shows corrosiveness in biodiesel [76]. Another work by Ononiwo et al. investigated MS for corrosion by immersion tests using ghee butter-based biodiesel at room temperature and different temperatures. The weight losses in mineral diesel and biodiesel samples were quite close. MS showed a similar response in all the media studied. Mineral diesel showed lower weight loss than samples 1 and 2, as shown in Table 5 [4]. The corrosion rate was increased by the increase in the temperature. 
Table 3. Summary of corrosion studies using rapeseed biodiesel.

\begin{tabular}{|c|c|c|c|c|c|c|c|c|}
\hline Sr. No. & Test Type & Material & Biofuel Blends & Temperature & Time & Characterization & TAN (mg KOH/g) & Corrosion Rate \\
\hline 1. & Immersion Test & Carbon Steel & - & Room temperature & $1176 \mathrm{~h}$ & - & Increased & $\begin{array}{c}\text { Corrosion rates in corn, } \\
\text { rapeseed and sunflower } \\
\text { biodiesels were } \\
0.001164,0.000760 \text { and } \\
0.000855 \mathrm{~mm} / \text { year, } \\
\text { respectively [63] }\end{array}$ \\
\hline 2. & Immersion Test & $\begin{array}{c}\text { Copper, } \\
\text { Aluminum, } \\
\text { Stainless Steel, } \\
\text { Mild Carbon Steel }\end{array}$ & B20 & $43^{\circ} \mathrm{C}$ & 2 months & $\begin{array}{c}\text { SEM/EDS, XPS, } \\
\text { AAS }\end{array}$ & - & $\begin{array}{l}\text { The corrosion rates of } \\
\text { copper and mild carbon } \\
\text { steel were } 0.02334 \text { and } \\
0.01819 \mathrm{~mm} / \text { year in } \\
\text { biodiesel while } 0.0037 \\
\text { and } 0.0015 \mathrm{~mm} / \text { year for } \\
\text { diesel, respectively [ } 71]\end{array}$ \\
\hline 3. & Immersion Test & $\begin{array}{l}\text { AW } 6060 \\
\text { Aluminum alloy, } \\
\text { E-Cu57 Copper }\end{array}$ & B0, B50, B75, B100 & $80^{\circ} \mathrm{C}$ & $600 \mathrm{~h}$ & SEM/EDS & $\begin{array}{c}\text { More than the } \\
\text { ASTM D6751 limit } \\
\text { of } 0.8\end{array}$ & $\begin{array}{l}\text { The increase in biodiesel } \\
\text { concentration and the } \\
\text { temperature increased } \\
\text { the corrosion rate of the } \\
\text { biodiesel [72] }\end{array}$ \\
\hline
\end{tabular}


Table 4. Summary of corrosion studies using sunflower biodiesel.

\begin{tabular}{|c|c|c|c|c|c|c|c|c|}
\hline Sr. No. & Test Type & Material & Biofuel Blends & Temperature & Time & Characterization & TAN (mg KOH/g) & Corrosion Rate \\
\hline 1. & Immersion Test & Brass & B0, B10, B20, B40 & Room temperature & $240,480,720,960 \mathrm{~h}$ & JCM 100 mini SEM & $\begin{array}{c}0.297 \text { (as-received), } \\
0.35 \text { (B0), 0.4 (B10), } \\
0.47 \text { (B20), 0.73 } \\
\text { (B40), } 1.95 \text { (B100) }\end{array}$ & $\begin{array}{l}\text { Increased duration and } \\
\text { biodiesel fraction } \\
\text { increased the corrosion } \\
\text { rate [73] }\end{array}$ \\
\hline 2. & Immersion Test & $\begin{array}{l}\text { Aluminum, } \\
\text { Copper, Mild } \\
\text { Carbon Steel }\end{array}$ & B0, B20, B100 & $\begin{array}{c}\text { Room } \\
\text { temperature, } 60^{\circ} \mathrm{C}\end{array}$ & $3000 \mathrm{~h}$ & SEM/EDS, XRD & - & $\begin{array}{c}\text { At } \mathrm{RT} \text {, the CRs of } \\
\text { copper, aluminum and } \\
\text { mild carbon steel were } \\
0.323615,0.162201 \text { and } \\
0.170124 \text { mpy, } \\
\text { respectively, and at } 60 \\
{ }^{\circ} \mathrm{C} \text {, these results were } \\
0.640758,0.316292 \text { and } \\
0.336845 \text { mpy, } \\
\text { respectively [74] }\end{array}$ \\
\hline 3. & $\begin{array}{l}\text { Electrochemical } \\
\text { Method }\end{array}$ & $\begin{array}{l}\text { Monel Steel, } \\
\text { Stainless Steel, } \\
\text { Mild Steel }\end{array}$ & 1,5 and 10 percent & $50{ }^{\circ} \mathrm{C}$ & $3 \mathrm{~h}$ & - & $\begin{array}{c}0.12 \text { (as-received), } \\
0.18 \text { (B1), } 0.2 \text { (B5), } \\
0.21 \text { (B10), } 0.3 \\
\text { (B100) }\end{array}$ & $\begin{array}{l}\text { The CR of monel steel } \\
\text { was } 0.000045 \mathrm{~mm} / \text { year, } \\
\text { stainless steel was } \\
0.000421 \mathrm{~mm} / \text { year and } \\
\text { mild carbon steel was } \\
0.000514 \mathrm{~mm} / \text { year. } \\
\text { Corrosion of these } \\
\text { materials was lowest in } \\
\text { pure diesel than in } \\
\text { biodiesel. [75] }\end{array}$ \\
\hline
\end{tabular}


Table 5. Summary of corrosion studies on biodiesel of different feedstock.

\begin{tabular}{|c|c|c|c|c|c|c|c|c|}
\hline Sr. No. & Test Type & Biodiesel & Material & Biofuel Blends & Temperature & Time & Characterization & $\begin{array}{c}\text { Corrosion } \\
\text { Rate/Findings }\end{array}$ \\
\hline 1. & Electrochemical & Canola & Aluminum & - & - & - & - & $\begin{array}{l}\text { The corrosion of } \\
\text { Aluminum can be } \\
\text { used as an indicator to } \\
\text { assess the purity of } \\
\text { the biodiesel [76] }\end{array}$ \\
\hline 2. & Immersion Test & Ghee Butter & Mild Steel & - & $\begin{array}{c}\text { Room } \\
\text { temperature, } \\
\text { Different } \\
\text { temperatures }\end{array}$ & - & - & $\begin{array}{l}\text { Biodiesel samples } \\
\text { were more corrosive } \\
\text { than mineral diesel } \\
\text { samples. The CR was } \\
\text { increased with the } \\
\text { increase in the } \\
\text { temperature [4] }\end{array}$ \\
\hline 3. & Immersion Test & Rice Husk & $\begin{array}{l}\text { Austenite Stainless } \\
\text { Steel, Brass, Mild } \\
\text { Steel, Aluminum }\end{array}$ & $\mathrm{B} 10, \mathrm{~B} 30$ & $\begin{array}{c}\text { Room } \\
\text { temperature, } 50 \\
{ }^{\circ} \mathrm{C}, 70{ }^{\circ} \mathrm{C}\end{array}$ & $\begin{array}{c}6,12,24,48,72 \\
120 \mathrm{~h}\end{array}$ & XPS & $\begin{array}{l}\text { Brass exhibited very } \\
\text { slight weight loss, } \\
\text { Aluminum exhibited } \\
\text { little more than Brass } \\
\text { and Mild Steel } \\
\text { exhibited more weight } \\
\text { loss than both } \\
\text { Aluminum and Brass. } \\
\text { At elevated } \\
\text { temperatures, the } \\
\text { weight loss was } \\
\text { enhanced for the } \\
\text { above-mentioned } \\
\text { materials. Stainless } \\
\text { Steel did not show } \\
\text { any weight loss at any } \\
\text { conditions [77] }\end{array}$ \\
\hline
\end{tabular}


Table 5. Cont

\begin{tabular}{|c|c|c|c|c|c|c|c|c|}
\hline Sr. No. & Test Type & Biodiesel & Material & Biofuel Blends & Temperature & Time & Characterization & $\begin{array}{c}\text { Corrosion } \\
\text { Rate/Findings }\end{array}$ \\
\hline 4. & Electrochemical & Soybean & $\begin{array}{l}\text { Duplex 2205, Sea } \\
\text { Curve, AISI } 3041\end{array}$ & - & Room temperature & $20 \mathrm{~h}$ & - & $\begin{array}{c}\text { The best resistance } \\
\text { towards corrosion } \\
\text { was shown by Duplex } \\
2205 \text { while Sea Curve } \\
\text { steel showed the least } \\
\text { corrosion resistance } \\
\text { [78] }\end{array}$ \\
\hline 5. & Immersion Test & Commercial & Copper, Brass & - & $55^{\circ} \mathrm{C}$ & 5 days & $\begin{array}{c}\text { Raman Vibrational } \\
\text { Spectroscopy }\end{array}$ & $\begin{array}{c}\text { The rate of corrosion } \\
\text { was slightly higher in } \\
\text { the case of incidence } \\
\text { light. At higher } \\
\text { temperature, } \\
\text { corrosion rates have } \\
\text { decreased. The CRs } \\
\text { for Brass are always } \\
\text { more than those of } \\
\text { Copper [1] }\end{array}$ \\
\hline 6. & Immersion Test & Poultry Fat & $\begin{array}{c}316 \text { Stainless Steel, } \\
\text { Grey Cast Iron, } \\
\text { Copper, Admiralty } \\
\text { Brass, Carbon } \\
\text { Steel }\end{array}$ & B20, B80 & $38^{\circ} \mathrm{C}$ & 10 months & $\begin{array}{c}\text { Digital } \\
\text { Photography, } \\
\text { photo Microscopy }\end{array}$ & $\begin{array}{l}316 \text { Stainless Steel and } \\
\text { Carbon Steel had no } \\
\text { visible corrosion. } \\
\text { Copper showed huge } \\
\text { corrosiveness in } \\
\text { biodiesel. B20 had a } \\
\text { slightly lower } \\
\text { corrosion rate than } \\
\text { that of B80. In the case } \\
\text { of Brass, similar } \\
\text { trends to that of } \\
\text { Copper were } \\
\text { observed however } \\
\text { these were to a lesser } \\
\text { extent [79] }\end{array}$ \\
\hline
\end{tabular}


$\mathrm{B} 10$ and $\mathrm{B} 30$ blends of rice husk bio-oil were used by Lu et al. to assess the corrosion properties of four materials-SS, MS, BS and Al-by immersion tests at RT, 50 and $70{ }^{\circ} \mathrm{C}$ for $6,12,24,48,72$ and $120 \mathrm{~h}$. BS exhibited very slight weight loss, Al exhibited little more than BS and MS exhibited more weight loss than both Al and BS. SS did not show any weight loss at any conditions [77]. The corrosion resistance of Duplex 2205, Sea Curve and AISI 3041 stainless steel were additionally studied by Roman et al. in soybean biodiesel by an electrochemical technique at room temperature for $20 \mathrm{~h}$. It was observed that all the steels showed good performances towards the corrosion resistance. The most resistive towards corrosion was Duplex 2205, while Sea Curve steel showed the least corrosion resistance, as shown in Table 5. Therefore, it was concluded that all these steels can be used in applications that need to be in contact with soybean oil-based biodiesel [78].

A study was conducted by Aquino et al. to investigate $\mathrm{CRs}$ of $\mathrm{Cu}$ and BS when immersed in commercial biodiesel in the presence of natural light and temperature for 5 days at $55{ }^{\circ} \mathrm{C}$. The rate of corrosion was slightly higher in the case of incidence light. The corrosion rates for BS were always higher than those of $\mathrm{Cu}$. It was found that the corrosion rates decreased at high temperatures, as shown in Table 5, which is contradictory to expected results because normally increases in temperature increase corrosion rates because of the increase in the reaction rate. The reason behind this result could be the elimination of the absorbed oxygen at high temperatures in the biodiesel [1]. Another study was performed by Geller et al. to investigate corrosion behaviors of B20 and B80 blends of poultry fat biodiesel on stainless steel 316, grey cast iron, copper, admiralty brass and carbon steel. Static immersion tests were performed for 10 months at $38^{\circ} \mathrm{C}$. Stainless steel 316 and carbon steel showed no weight loss or visible corrosion. Copper showed huge corrosiveness in biodiesel. B20 had slightly lower weight loss $0.71 \%$ than that of B80 0.74\% [79].

As shown in Table 5, it is clear that all biodiesels showed increased corrosion rates for all materials by the increase in the concentration of biodiesel. There were few deviations shown by different biodiesels concerning duration and temperature; however, in most cases, the corrosion rate was increased by increasing the duration and temperature of immersion. Therefore, it is concluded that the CR of materials in biodiesel increases by increasing concentration, duration and temperature. Summaries of these studies have been shown in Table 5.

\section{Corrosion Mechanism of Metals in Biodiesel}

The X-ray Diffraction (XRD) results of $\mathrm{Cu}$ showed the formation of different compounds such as $\mathrm{Cu}_{2} \mathrm{O}, \mathrm{CuO}$ [80], $\mathrm{CuCO}_{3}$ [81] and $\mathrm{Cu}(\mathrm{OH})_{2}$ [82] on the surface of the base metal. The mechanism or reactions which took place during this process are stated below [83].

$$
\begin{gathered}
\mathrm{Cu}_{2} \mathrm{O}+1 / 2 \mathrm{O}_{2} \rightarrow 2 \mathrm{CuO} \\
\mathrm{Cu}_{2} \mathrm{O}+\mathrm{CO}_{2}+1 / 2 \mathrm{O}_{2} \rightarrow 2 \mathrm{CuCO}_{3} \\
\mathrm{CuO}+\mathrm{CO}_{2} \rightarrow \mathrm{CuCO}_{3} \\
2 \mathrm{Cu}+\mathrm{O}_{2}+2 \mathrm{H}_{2} \mathrm{O} \rightarrow 2 \mathrm{Cu}(\mathrm{OH})_{2} \\
\mathrm{CuO}+\mathrm{H}_{2} \rightarrow \mathrm{Cu}(\mathrm{OH})_{2}
\end{gathered}
$$

RCOO• radical [84] generation was thought to be the main cause of copper carbonate formation [85] through the decomposition of esters [86].

$$
\begin{gathered}
\mathrm{RCOOR}_{1} \rightarrow \mathrm{RCOO}^{*}+\mathrm{R}_{1}^{*} \\
2 \mathrm{RCOO}^{*}+\mathrm{Cu} \rightarrow \mathrm{CuCO}_{3}+\mathrm{R}-\mathrm{R}+\mathrm{CO} \\
2 \mathrm{Cu}(\mathrm{OH})_{2}+\mathrm{CO}_{2} \rightarrow 2 \mathrm{Cu}(\mathrm{OH})_{2} \cdot \mathrm{CuCO}_{3}+\mathrm{H}_{2} \mathrm{O}
\end{gathered}
$$

As iron is the main component of steel, when exposed to biodiesel, it is more prone to corrosion. Therefore, $\mathrm{XRD}$ results showed the formation of some iron products such as 
$\mathrm{Fe}_{2} \mathrm{O}_{3}$ [71], $\mathrm{Fe}(\mathrm{OH})_{2}$ [87] and $\mathrm{FeCO}_{3}$ [88]. The mechanism or reactions which took place during that process are stated below [89].

$$
\begin{gathered}
\mathrm{RCOOR}_{1} \rightarrow \mathrm{RCOO}^{*}+\mathrm{R}_{1}^{*} \\
4 \mathrm{Fe}+3 \mathrm{O}_{2} \rightarrow 2 \mathrm{Fe}_{2} \mathrm{O}_{3} \\
2 \mathrm{Fe}+\mathrm{O}_{2}+2 \mathrm{H}_{2} \mathrm{O} \rightarrow 2 \mathrm{Fe}(\mathrm{OH})_{2} \\
4 \mathrm{Fe}(\mathrm{OH})_{2}+\mathrm{O}_{2} \rightarrow 2 \mathrm{Fe}_{2} \mathrm{O}_{3} . \mathrm{H}_{2} \mathrm{O}+2 \mathrm{H}_{2} \mathrm{O} \\
\mathrm{RCOOR}_{1} \rightarrow \mathrm{RCOO}^{*}+\mathrm{R}_{1}^{*} \\
2 \mathrm{RCOO}^{*}+\mathrm{Fe} \rightarrow \mathrm{FeCO}_{3}+\mathrm{R}-\mathrm{R}+\mathrm{CO}-
\end{gathered}
$$

\section{Characterization Techniques Used}

Characterization techniques that have been used by researchers for corrosion testing include Scanning Electron Microscope/Energy Dispersive Spectroscopy (SEM/EDS), X-ray diffraction (XRD), Optical Microscopy (OM), X-ray Photoelectron Spectroscopy (XPS), Atomic Absorption Spectrometry (AAS) and Raman vibrational spectroscopy. SEM/EDS and XRD used by researchers concerning the biodiesel are stated below.

\subsection{Characterization and Products of Corrosion Obtained by Palm Biodiesel}

When palm biodiesel was used to find CRs of copper and leaded bronze, the oxide layer obtained at RT was copper carbonate $\left(\mathrm{CuCO}_{3}\right)$ and at $60{ }^{\circ} \mathrm{C}$ was of cupric oxide $(\mathrm{CuO})$ [55].

When palm biodiesel was used to find the CR of CS ASTM 1045 at 27,50 and $80^{\circ} \mathrm{C}$ for 30, 60 and 120 days, SEM results showed that the effects of corrosion become severe as the exposure time and temperature were increased, as shown in the Figures 9 and 10. The attacked zones were not continuous and were scattered over the whole surface.
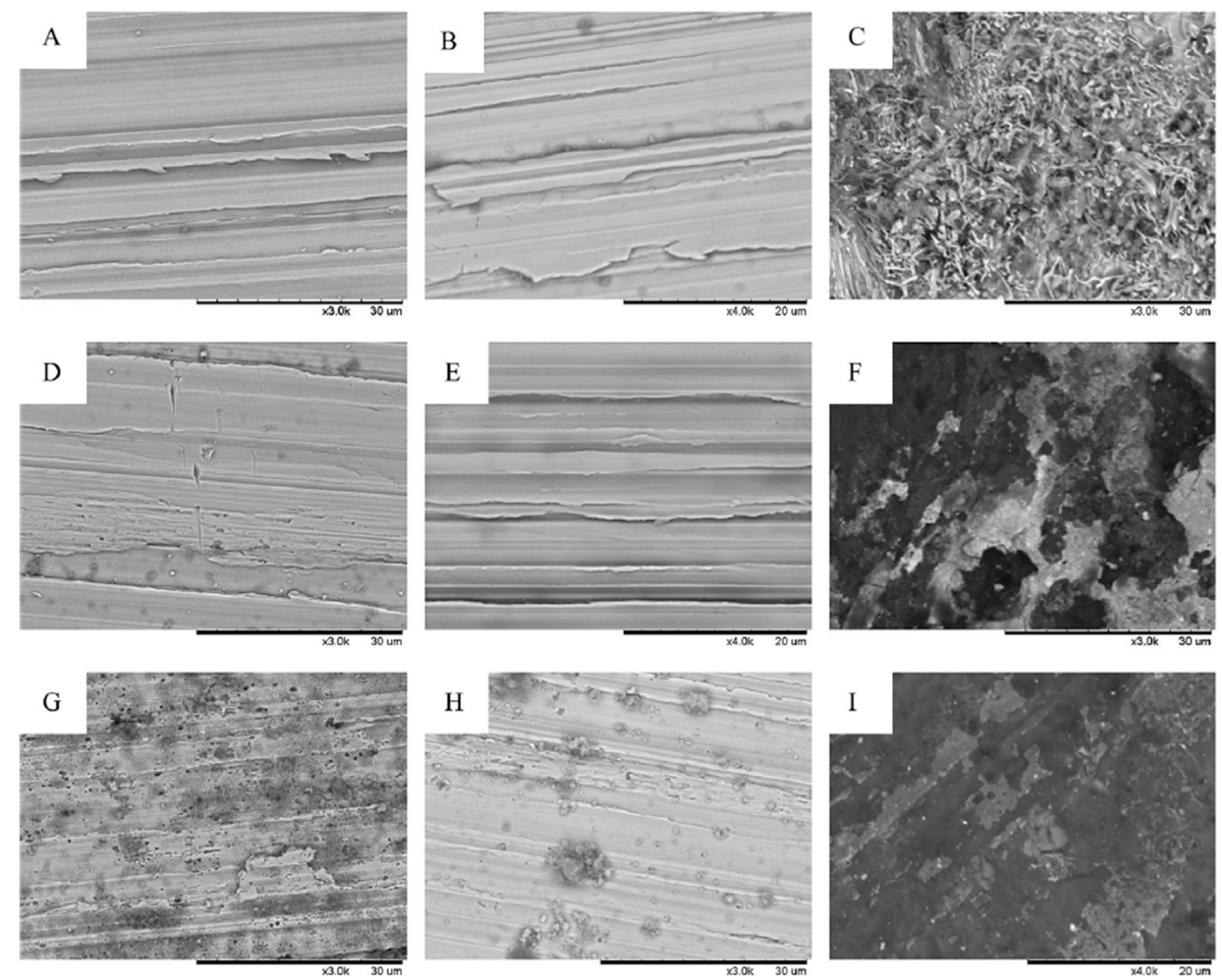

Figure 9. Surface morphology of ASTM $1045 \mathrm{MS}$ in 0\# diesel at different temperatures 27,50 and $80{ }^{\circ} \mathrm{C}$ for different exposure periods: (A) $27^{\circ} \mathrm{C}-30 \mathrm{~d}$; (B) $50{ }^{\circ} \mathrm{C}-30 \mathrm{~d}$; (C) $80^{\circ} \mathrm{C}-30 \mathrm{~d}$; (D) $27^{\circ} \mathrm{C}-60 \mathrm{~d}$; (E) $50{ }^{\circ} \mathrm{C}-60 \mathrm{~d}$; (F) $80{ }^{\circ} \mathrm{C}-60 \mathrm{~d}$; (G) $27^{\circ} \mathrm{C}-120 \mathrm{~d} ;(\mathbf{H}) 50{ }^{\circ} \mathrm{C}-120 \mathrm{~d} ;$ (I) $80^{\circ} \mathrm{C}-120 \mathrm{~d}$ [66]. 

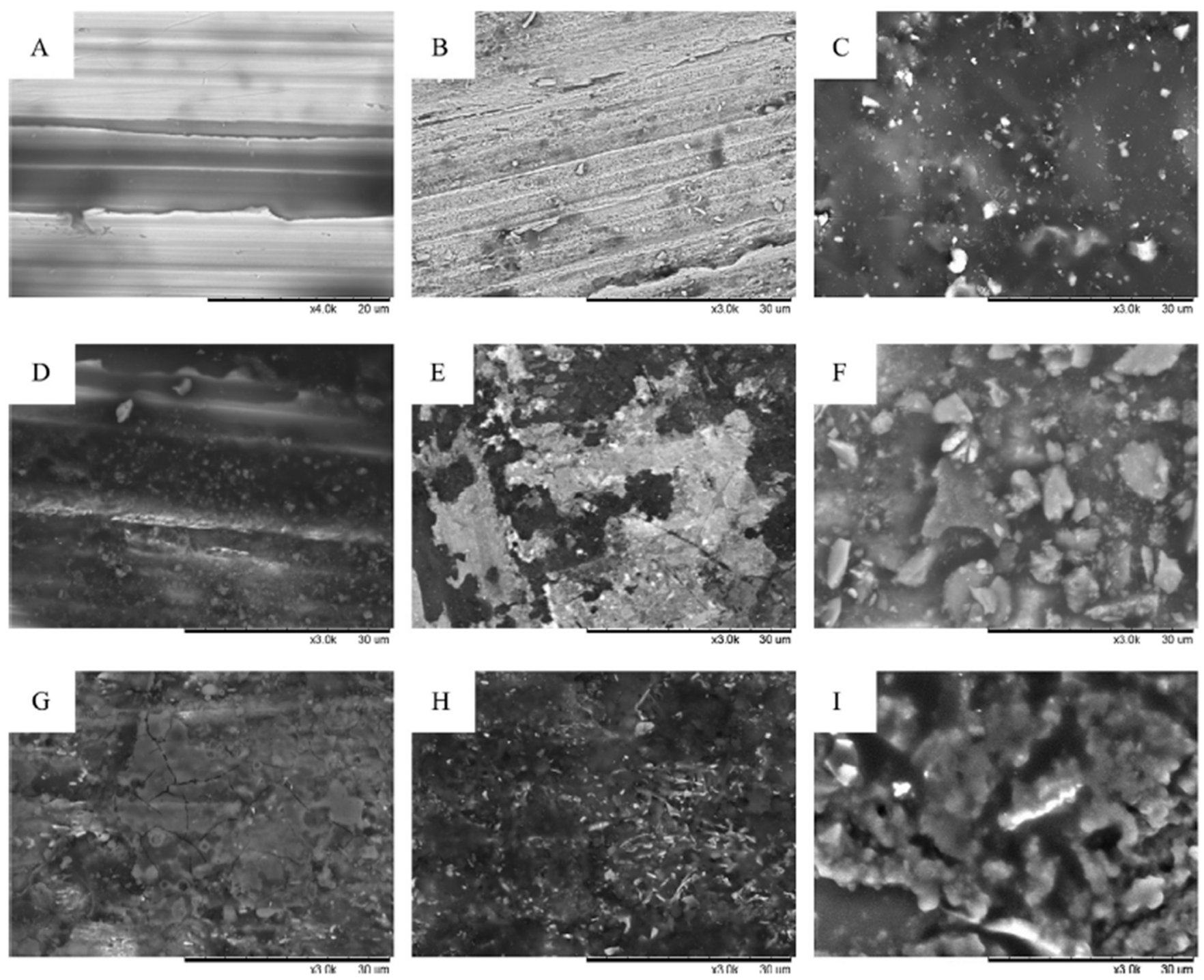

Figure 10. Surface morphology of ASTM $1045 \mathrm{MS}$ in palm biodiesel at different temperatures 27,50 and $80{ }^{\circ} \mathrm{C}$ for different exposure periods: (A) $27^{\circ} \mathrm{C}-30 \mathrm{~d}$; (B) $50{ }^{\circ} \mathrm{C}-30 \mathrm{~d}$; (C) $80{ }^{\circ} \mathrm{C}-30 \mathrm{~d}$; (D) $27^{\circ} \mathrm{C}-60 \mathrm{~d}$; (E) $50{ }^{\circ} \mathrm{C}-60 \mathrm{~d}$; (F) $80{ }^{\circ} \mathrm{C}-60 \mathrm{~d}$; (G) $27^{\circ} \mathrm{C}-120 \mathrm{~d}$; (H) $50{ }^{\circ} \mathrm{C}-120 \mathrm{~d}$; (I) $80{ }^{\circ} \mathrm{C}-120 \mathrm{~d}[66]$.

XRD showed that the compounds formed on the surface of MS in biodiesel were $\mathrm{Fe}_{2} \mathrm{O}_{3}, \mathrm{FeO}(\mathrm{OH}), \mathrm{Fe}_{2} \mathrm{O}_{2} \mathrm{CO}_{3}, \mathrm{FeO}$ and $\mathrm{FeCO}_{3}$. The products formed on the commercial diesel surface were $\mathrm{FeO}, \mathrm{FeO}(\mathrm{OH})$ and $\mathrm{Fe}_{2} \mathrm{O}_{3}$, as shown in Figure 11 [66].

When palm biodiesel was used to find $\mathrm{CR}$ of $\mathrm{Al}$ and $\mathrm{Mg}$ at RT for 720 and $1440 \mathrm{~h}$, on the SEM image at 1000X magnification of the as-received materials, only grinding lines were visible. At $1440 \mathrm{~h}$, again grinding lines were visible on the material surface of $\mathrm{Al}$, therefore it did not achieve any significant change. However, the surface of $\mathrm{Mg}$ showed significant change and its surface was degraded because of the corrosion attack, as shown in Figure 12. XRD analysis did not show the formation of any compound on the surface of both materials [68]. 

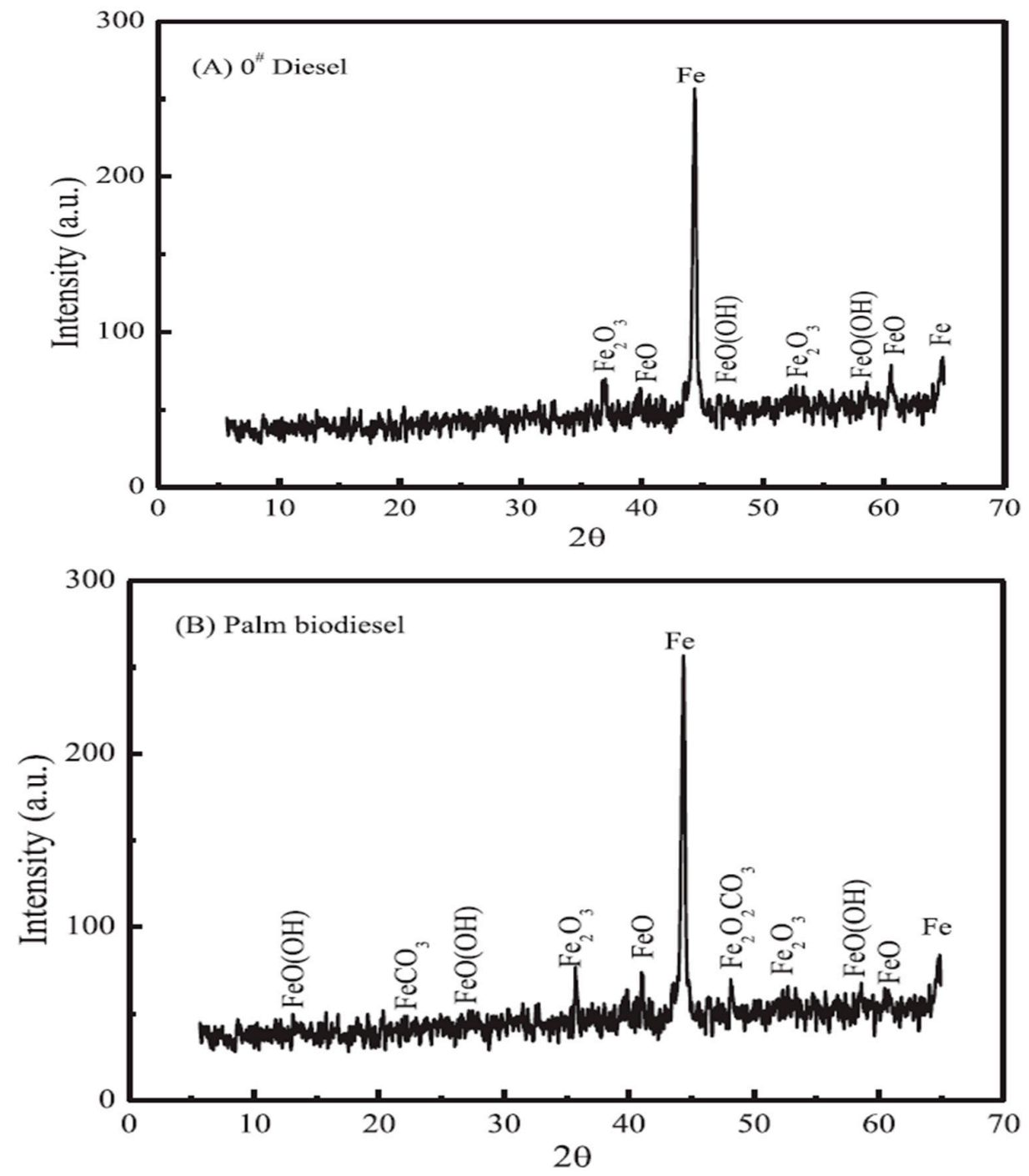

Figure 11. Corrosion products formed on MS at \#0 diesel and biodiesel [66].
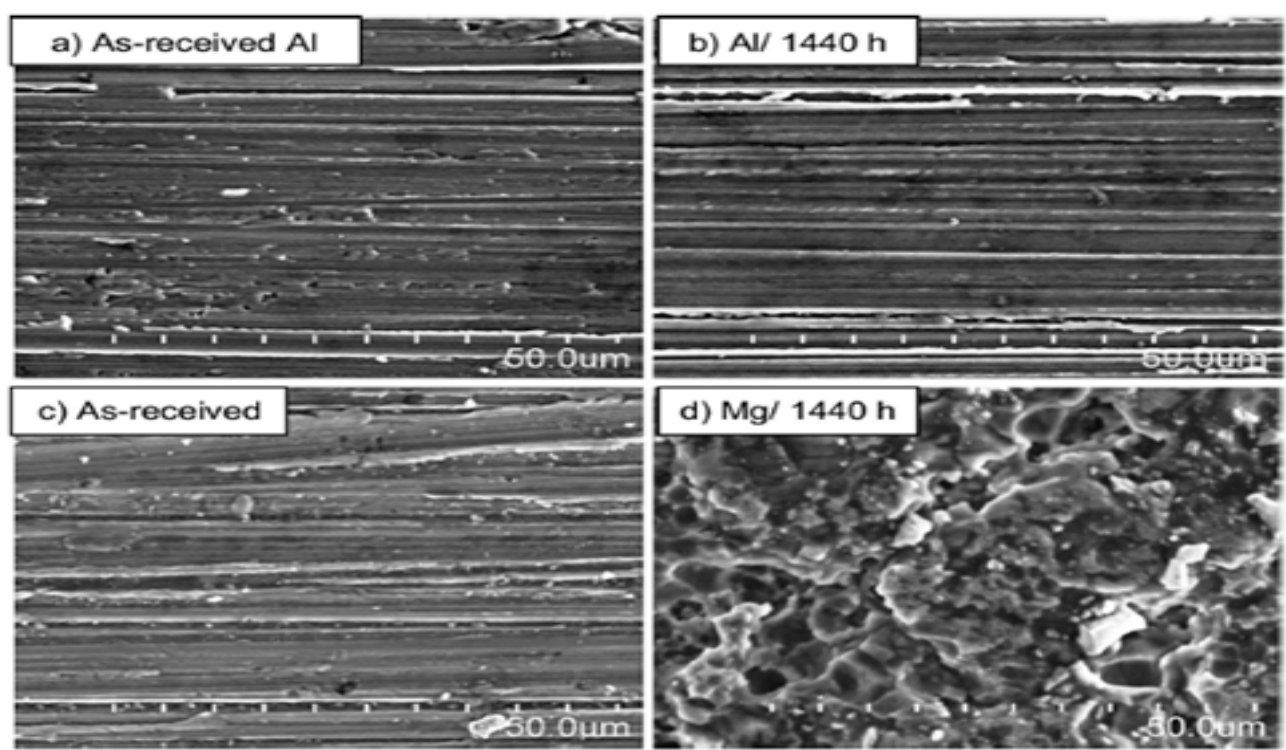

Figure 12. Scanning Electron Microscope (SEM) image of $\mathrm{Mg}$ and $\mathrm{Al}$ before and after immersion [68]. 
When palm biodiesel was used to find corrosion rates of MS at RT, 50 and $80{ }^{\circ} \mathrm{C}$ for $1200 \mathrm{~h}$, the XRD results showed the presence of certain compounds on the surface. Biodiesel had $\mathrm{Fe}_{2} \mathrm{O}_{3}, \mathrm{Fe}_{2} \mathrm{O}_{2} \mathrm{CO}_{3}$ and $\mathrm{Fe}(\mathrm{OH})_{3}$ while diesel showed only $\mathrm{Fe}_{2} \mathrm{O}_{3}$ and $\mathrm{Fe}(\mathrm{OH})_{3}$, as shown in Figure 13 [67]. Figure 14 shows the SEM images of samples before and after the immersion. It can be clearly seen that materials exhibit corrosion after the immersion. The zones where corrosion attacked are discontinued and scattered over the surface.
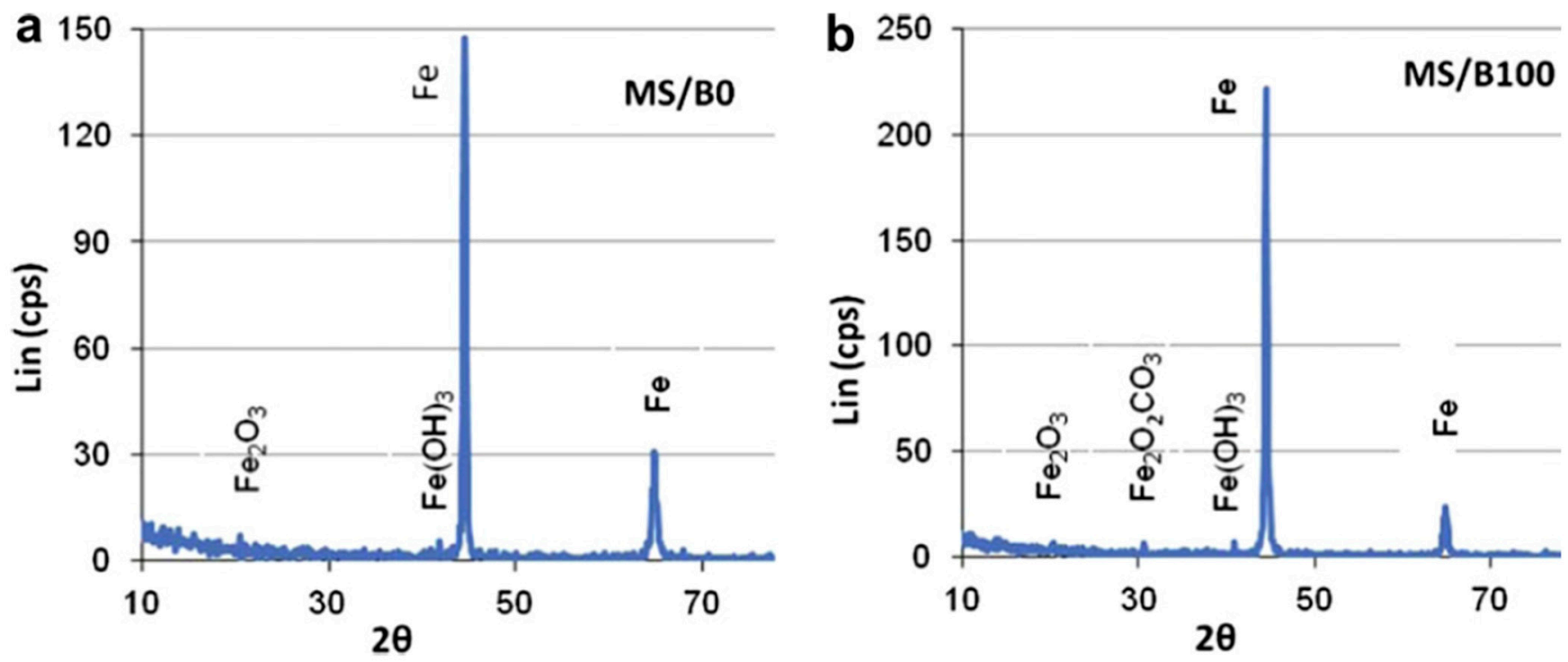

Figure 13. Corrosion products formed on MS upon exposure to diesel and biodiesel [67]. 


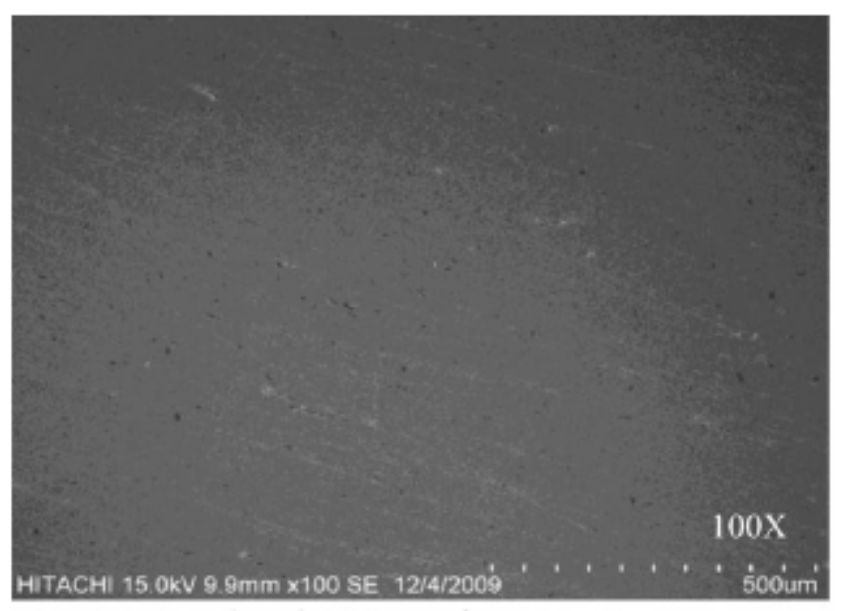

\section{As-received MS surface}
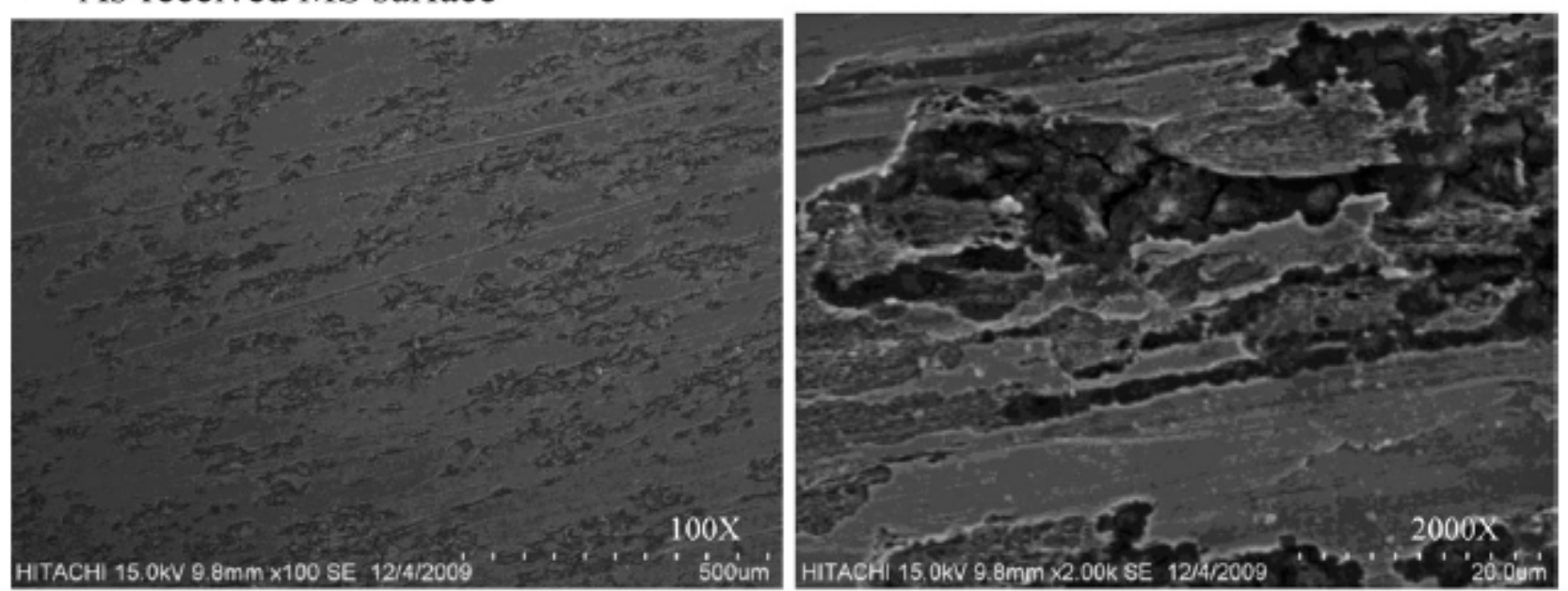

MS surface exposed to B0 at RT
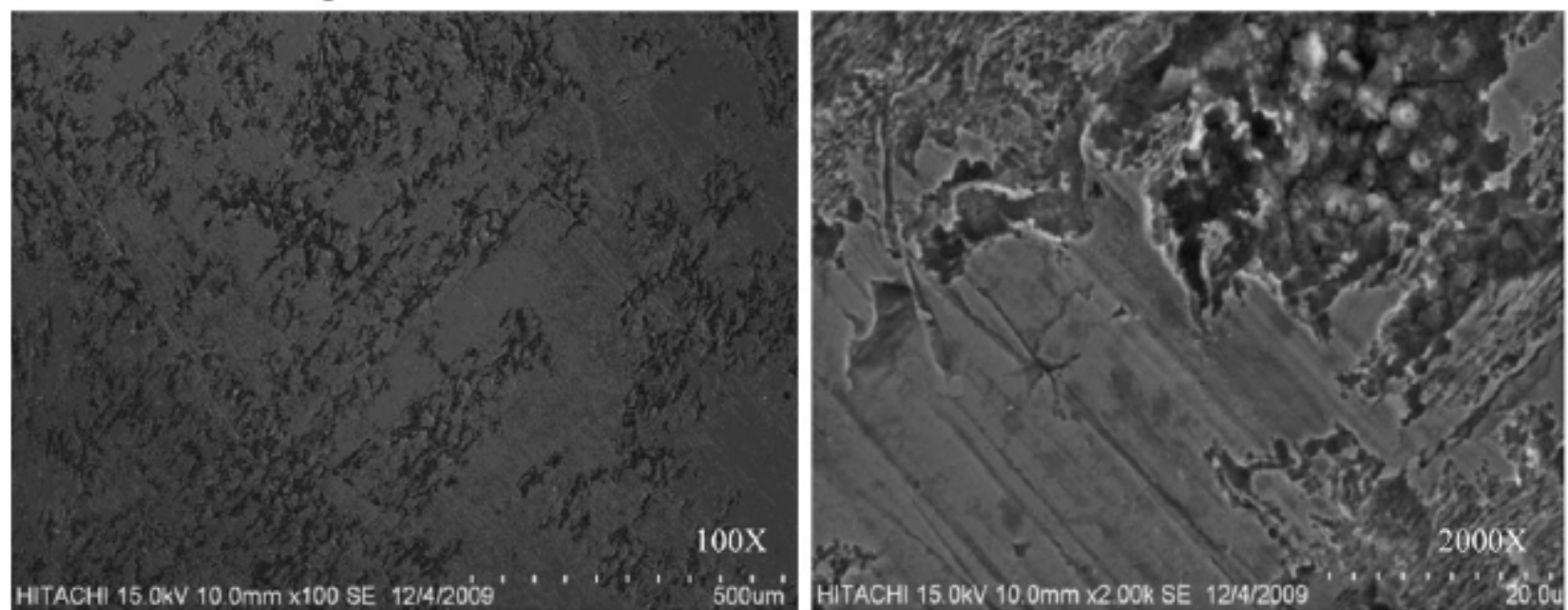

MS surface exposed to $\mathrm{B} 0$ at $80^{\circ} \mathrm{C}$

Figure 14. Cont. 


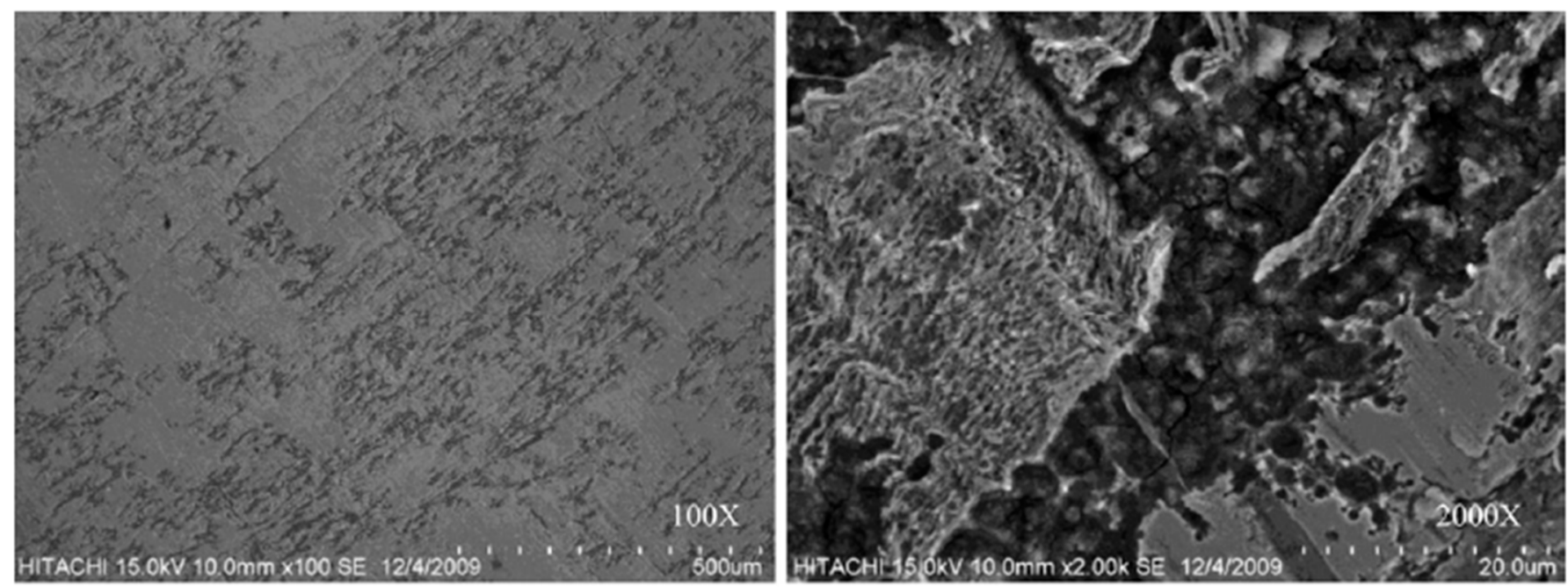

a MS surface exposed to B100 at RT
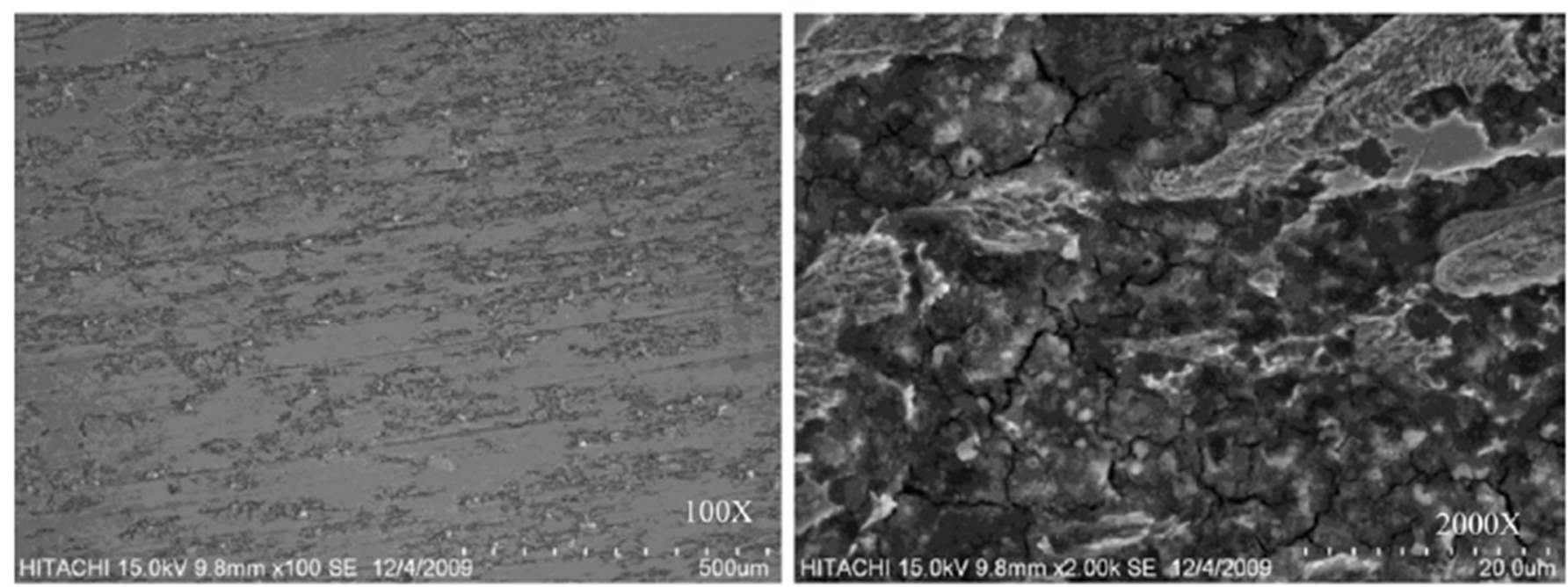

b MS surface exposed to $\mathrm{B} 100$ at $80^{\circ} \mathrm{C}$

Figure 14. SEM images of as-received MS and on exposure to B0 (up) and B100 (down) at room temperature and $80{ }^{\circ} \mathrm{C}$ [67].

When palm biodiesel was used for $\mathrm{Cu}$, BS, Al and CI at RT for $2880 \mathrm{~h}$, the XRD results in Figure 15i,ii showed the formation of $\mathrm{CuCO}_{3}$ in higher concentration along with $\mathrm{CuO}, \mathrm{CuCO}_{3} \cdot \mathrm{Cu}(\mathrm{OH})_{2}, \mathrm{Cu}(\mathrm{OH})_{2}$ and $\mathrm{Cu}_{2} \mathrm{O}$. Moreover, in brass, small amounts of $\mathrm{CuCO}_{3}$ seemed to form. In the case of aluminum, no compound was formed on its surface in biodiesel or diesel. SEM images in Figure 16 showed that the corrosion attack in biodiesel is more than that of diesel. Aluminum showed the lowest corrosion attack as compared to other materials [64]. 

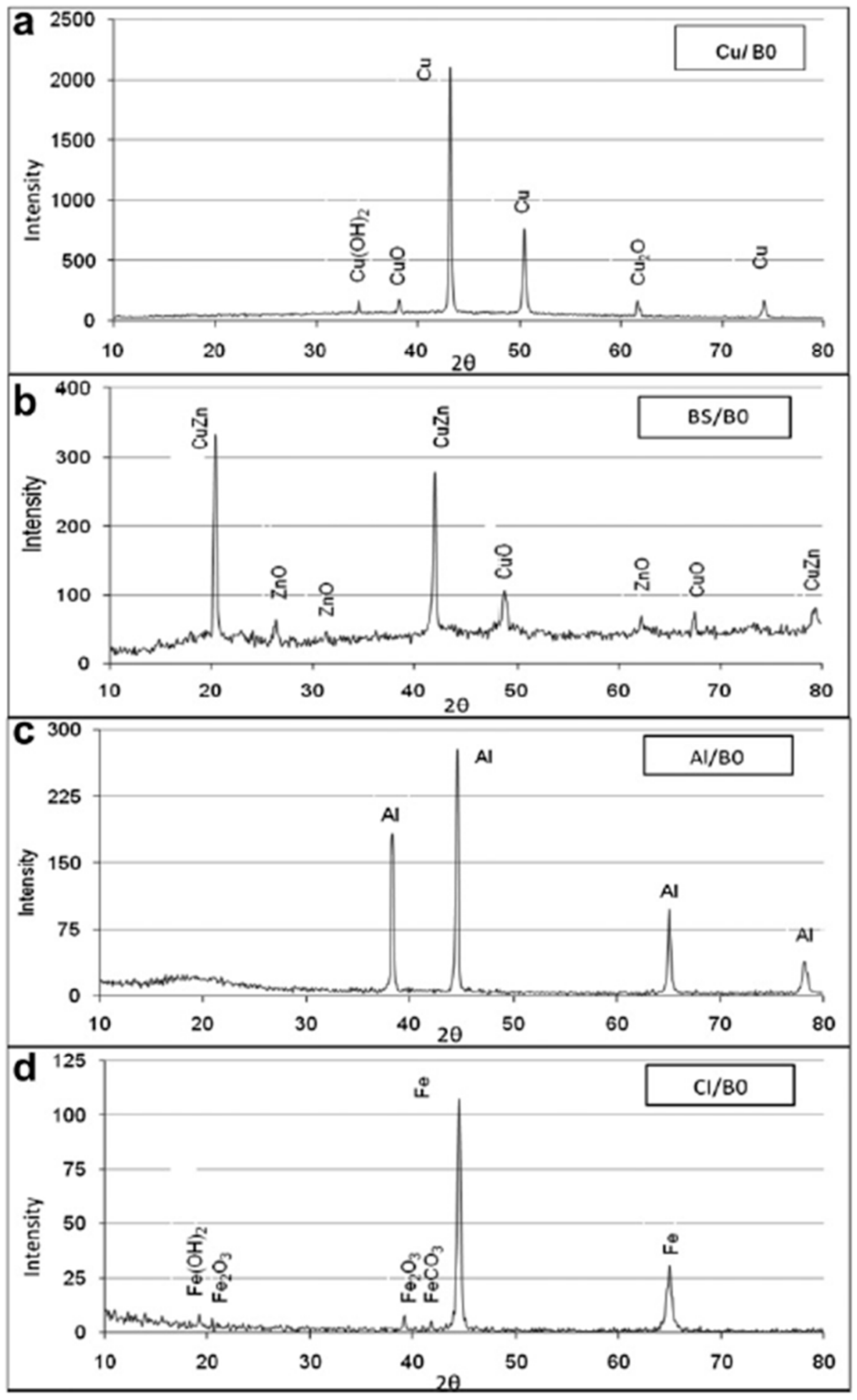

(i)

Figure 15. Cont. 

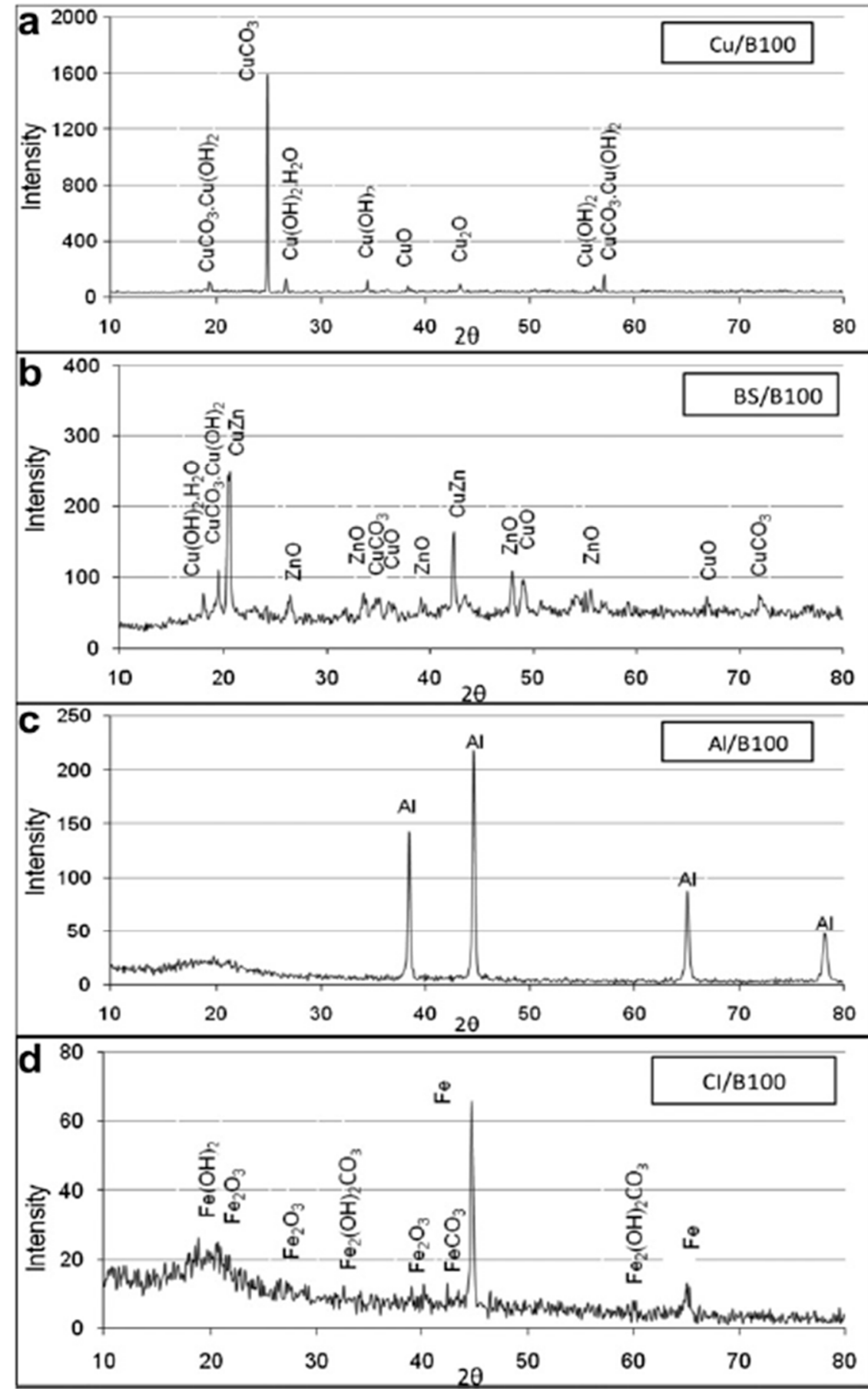

(ii)

Figure 15. (i) Products of corrosion formed on as-received materials and B0 and B100 blends [64]. (ii) Products of corrosion formed on as-received materials and B0 and B100 blends [64]. 

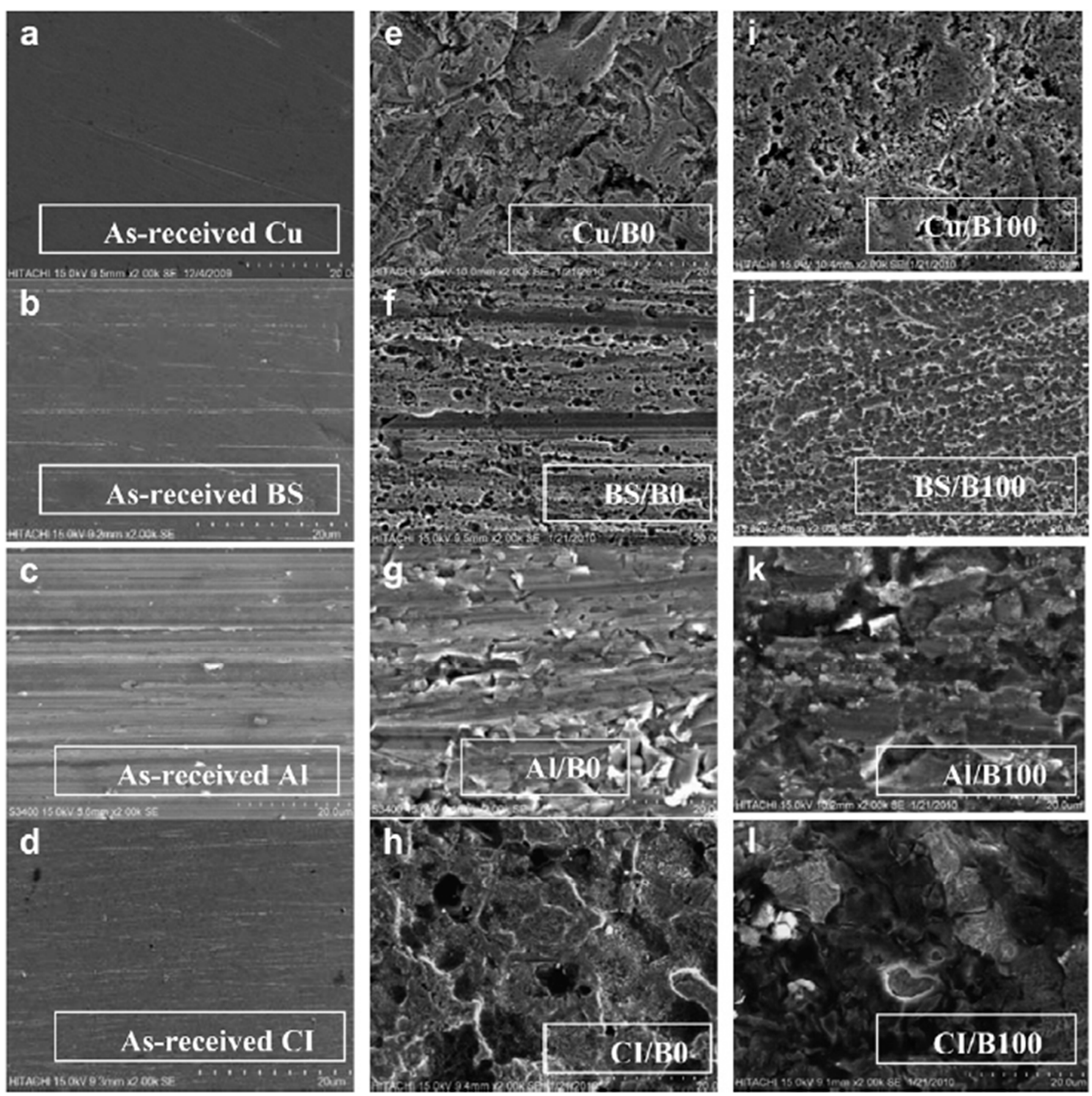

Figure 16. SEM images of as-received materials and when exposed to B0 and B100 blends [64].

\subsection{Characterization and Products of Corrosion Obtained by Rapeseed Biodiesel}

When the $\mathrm{CRs}$ of $\mathrm{Cu}, \mathrm{Al}$, SS and MCS were assessed by rapeseed biodiesel for two months at $43^{\circ} \mathrm{C}$, the SEM images of the materials showed that there were clear changes in the surface morphologies of all materials because of corrosion, except stainless steel, where only a small change was visible, as shown in Figure 17, which was because of the reaction with biodiesel. In the case of copper, a black layer covered its surface. The surface of aluminum was turned slightly dark. In the case of stainless steel, there were no changes on the surface. The XPS showed the formation of metal oxides including $\mathrm{CuO}, \mathrm{Cu}_{2} \mathrm{O}$, $\mathrm{Fe}_{2} \mathrm{O}_{3}[71]$. 


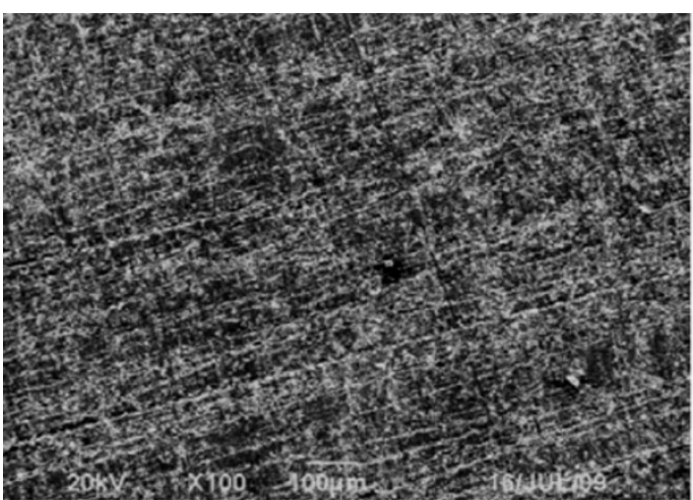

(a) Copper before corrosion

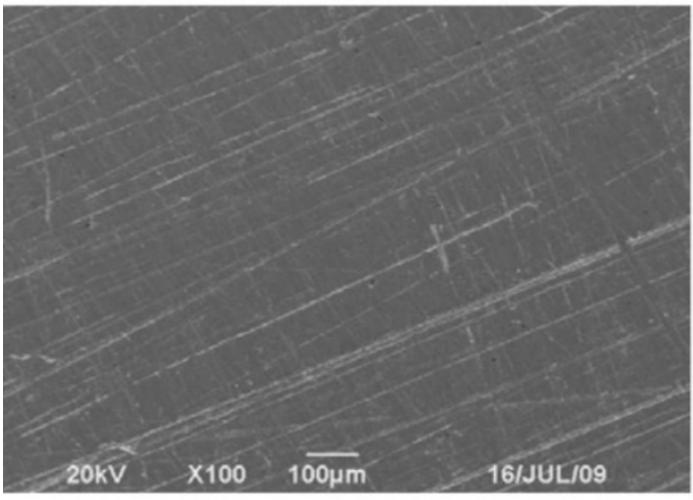

(b) Carbon steel before corrosion

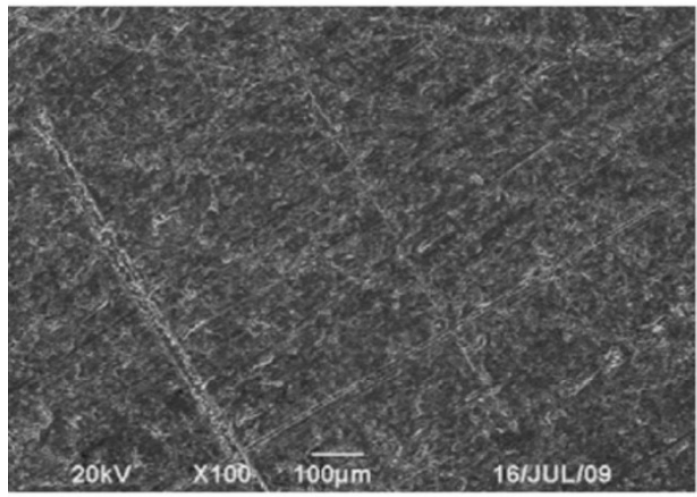

(c) Aluminium before corrosion

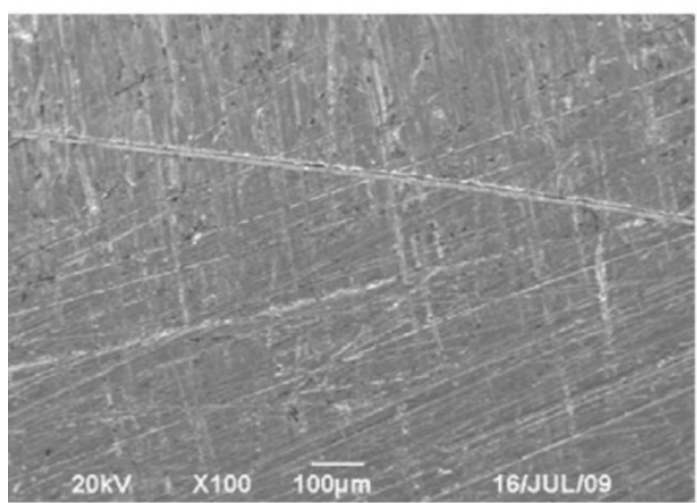

(d) Stainless steel before corrosion

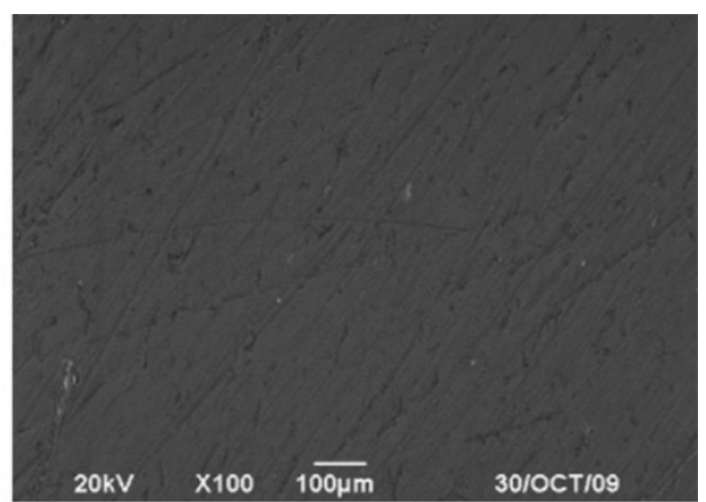

(a') Copper after corrosion

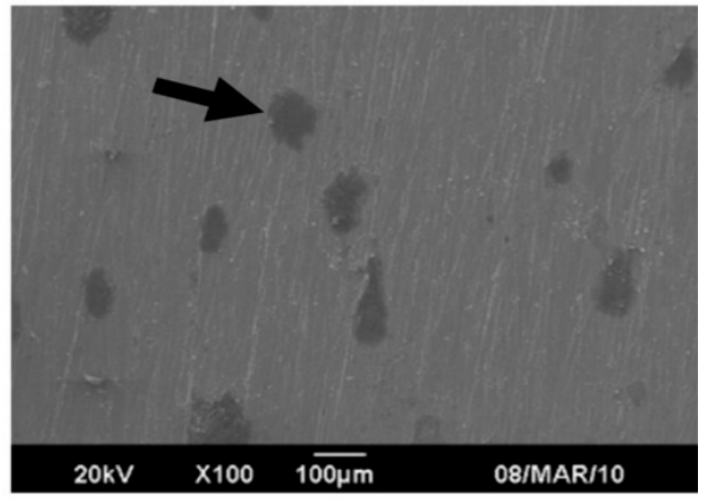

(b') Carbon steel after corrosion

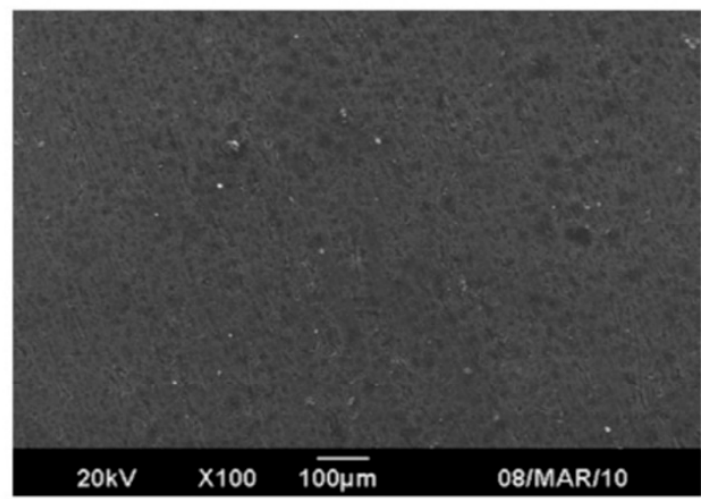

(c') Aluminium after corrosion

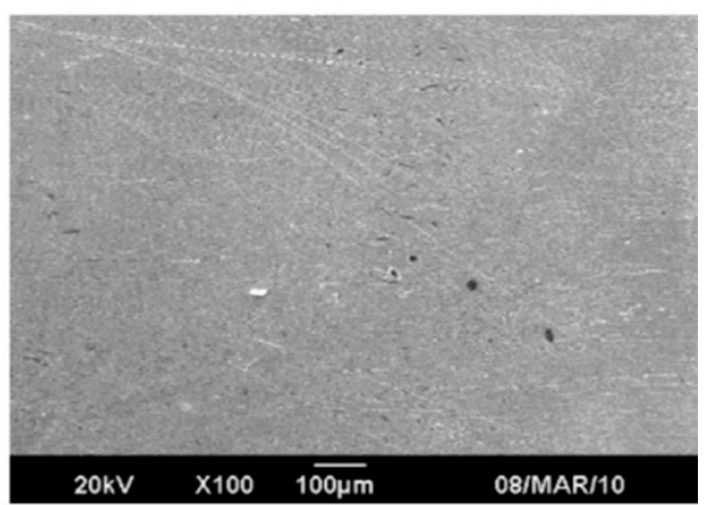

(d) Stainless steel after corrosion

Figure 17. SEM image of the metal surface before and after immersion [71]. 
When the corrosion rates of AW 6060 aluminum alloy and E-Cu57 copper were assessed by ultralow sulfur diesel (ULSD) and rapeseed methyl ester (RME) for $600 \mathrm{~h}$ at $80{ }^{\circ} \mathrm{C}$ in the reaction of aluminum and biodiesel, $\mathrm{Al}(\mathrm{OH})_{3}$ was found on the surface. Because of the presence of oxygen, another oxide layer $\mathrm{Al}_{2} \mathrm{O}_{3}$ was formed. In the case of copper, the compounds formed on the surface were $\mathrm{CuO} / \mathrm{CuCO}_{3}$ films followed by $\mathrm{Cu}_{2} \mathrm{O}$. The SEM images showed an increased concentration of biodiesel, which damaged the surface more and the pit generation can be seen to be increased, as in Figure 18 [72].

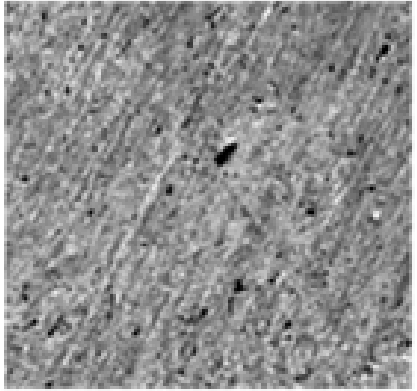

(A).Cu Exposed to 80

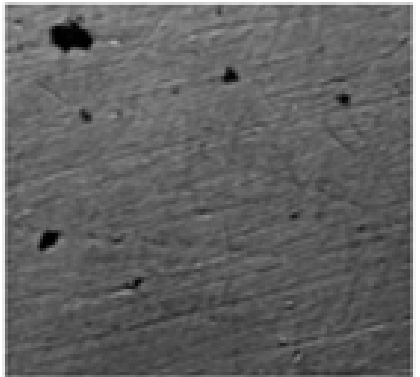

(E)-Al Exposed to 80

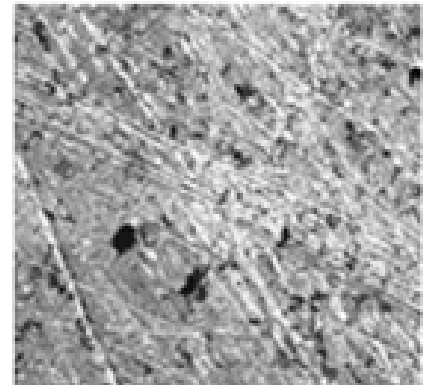

(B)-Cu Exposed to 850

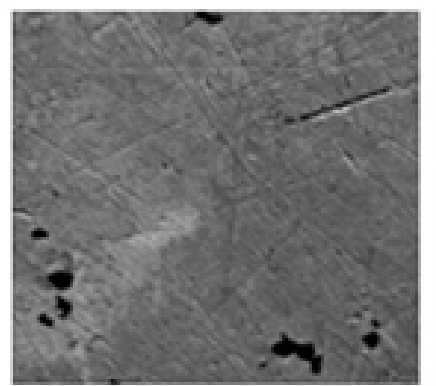

(F)-Al Exposed to 850

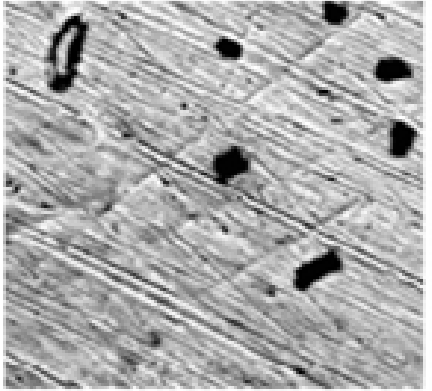

(C)-Cu Exposed to 875

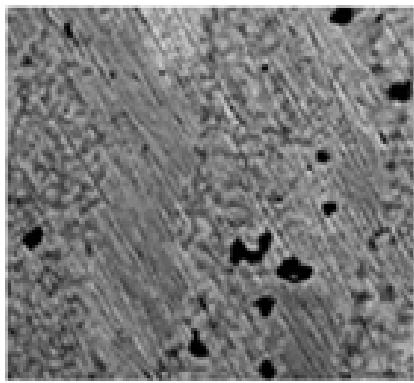

(G)-Al Exposed to 875

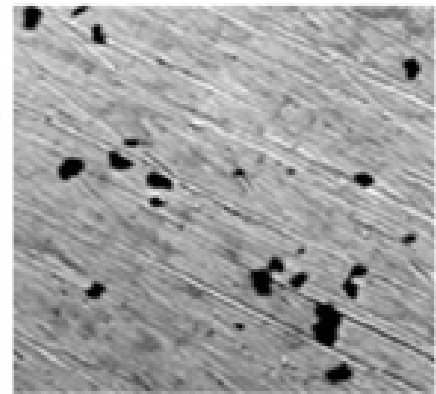

(D).Cu Exposed to 8100

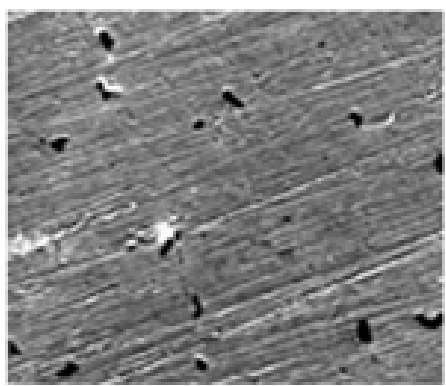

(H)-Al Exposed to $B 100$

Figure 18. SEM photographs of surfaces exposed to fuel blends [72].

\subsection{Characterization and Products of Corrosion Obtained by Sunflower Biodiesel}

When $\mathrm{CR}$ of $\mathrm{Al}, \mathrm{Cu}$ and MCS were assessed in sunflower biodiesel at RT and $60{ }^{\circ} \mathrm{C}$ for $3000 \mathrm{~h}$, the XRD patterns of the materials confirmed the presence of base metal along with the little quantities of $\mathrm{FeCO}_{3}, \mathrm{FeO}(\mathrm{OH}), \mathrm{Fe}_{2} \mathrm{O}_{3}, \mathrm{Cu}(\mathrm{OH})_{2}, \mathrm{CuO}$ and $\mathrm{AlO}(\mathrm{OH})$. SEM image of aluminum showed that at RT no corrosion attack was found; however, at $60{ }^{\circ} \mathrm{C}$, a protective layer covering the surface of the Al protected the metal surface from corrosion.

The SEM image of $\mathrm{Cu}$ in Figure 19 showed that at RT there was the visibility of a few small pit formations which indicated the initiation of corrosion, while at $60^{\circ} \mathrm{C}$, the formed pits were of larger size, which confirmed that the $\mathrm{Cu}$ had been corroded [74]. 

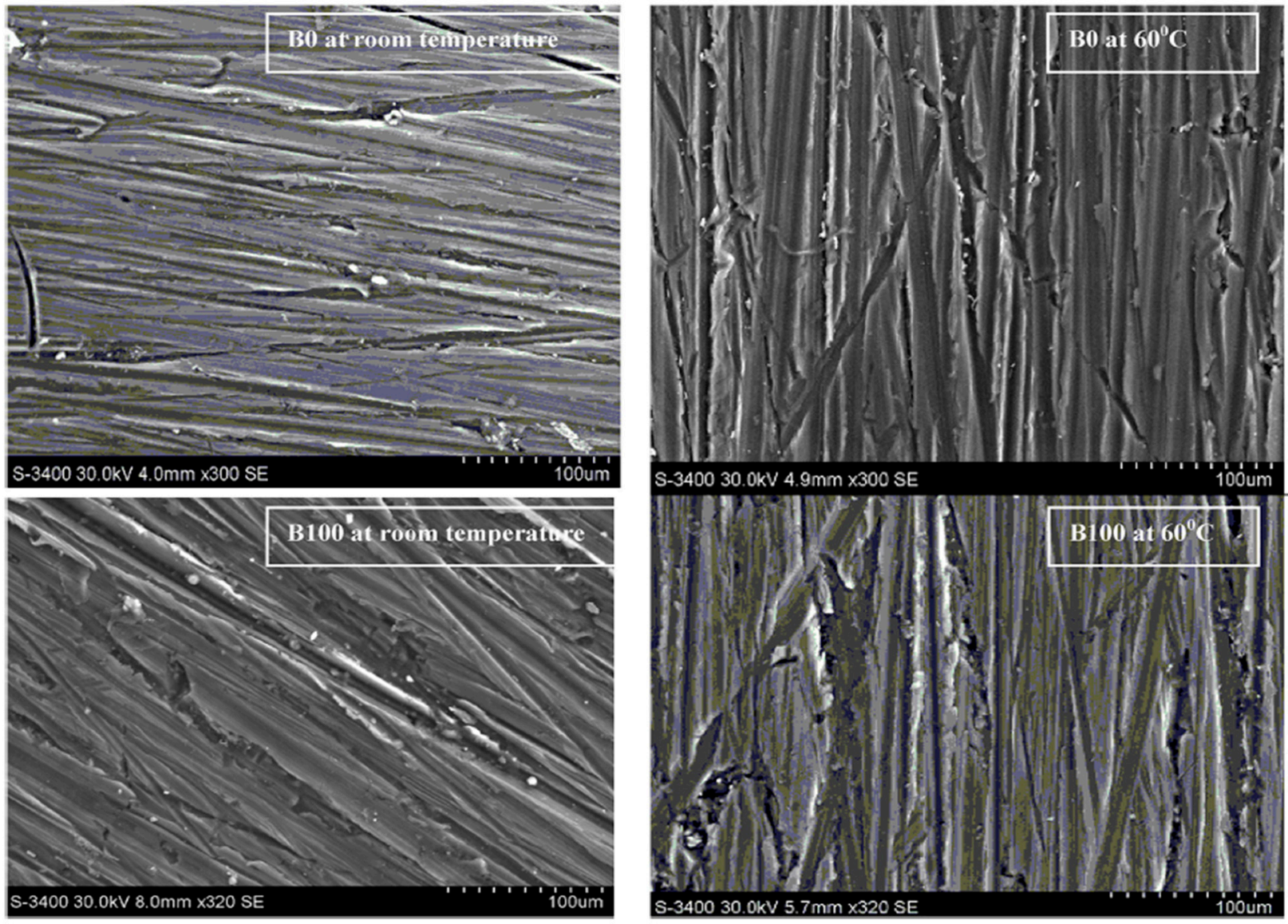

(i)
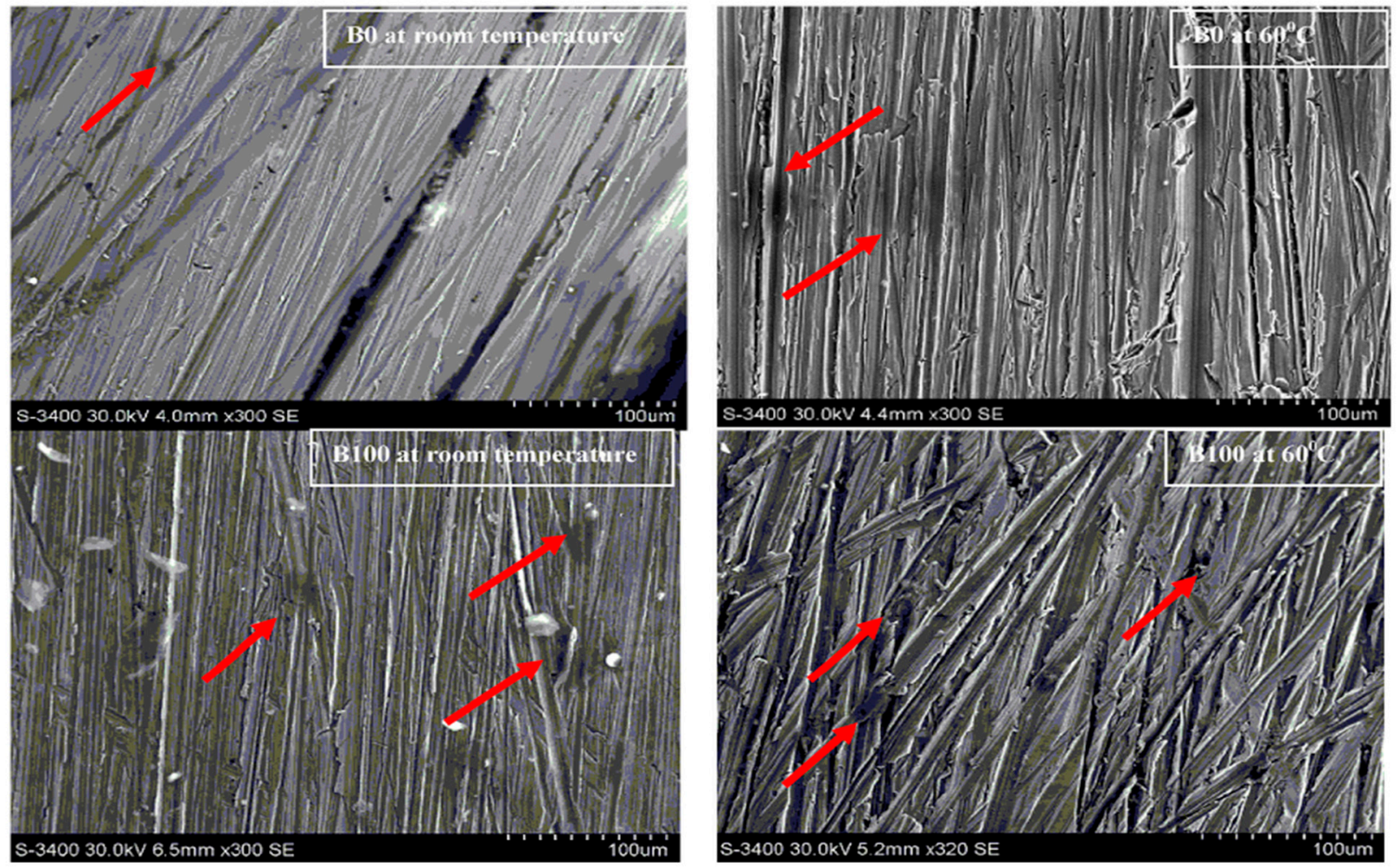

(ii)

Figure 19. Cont. 

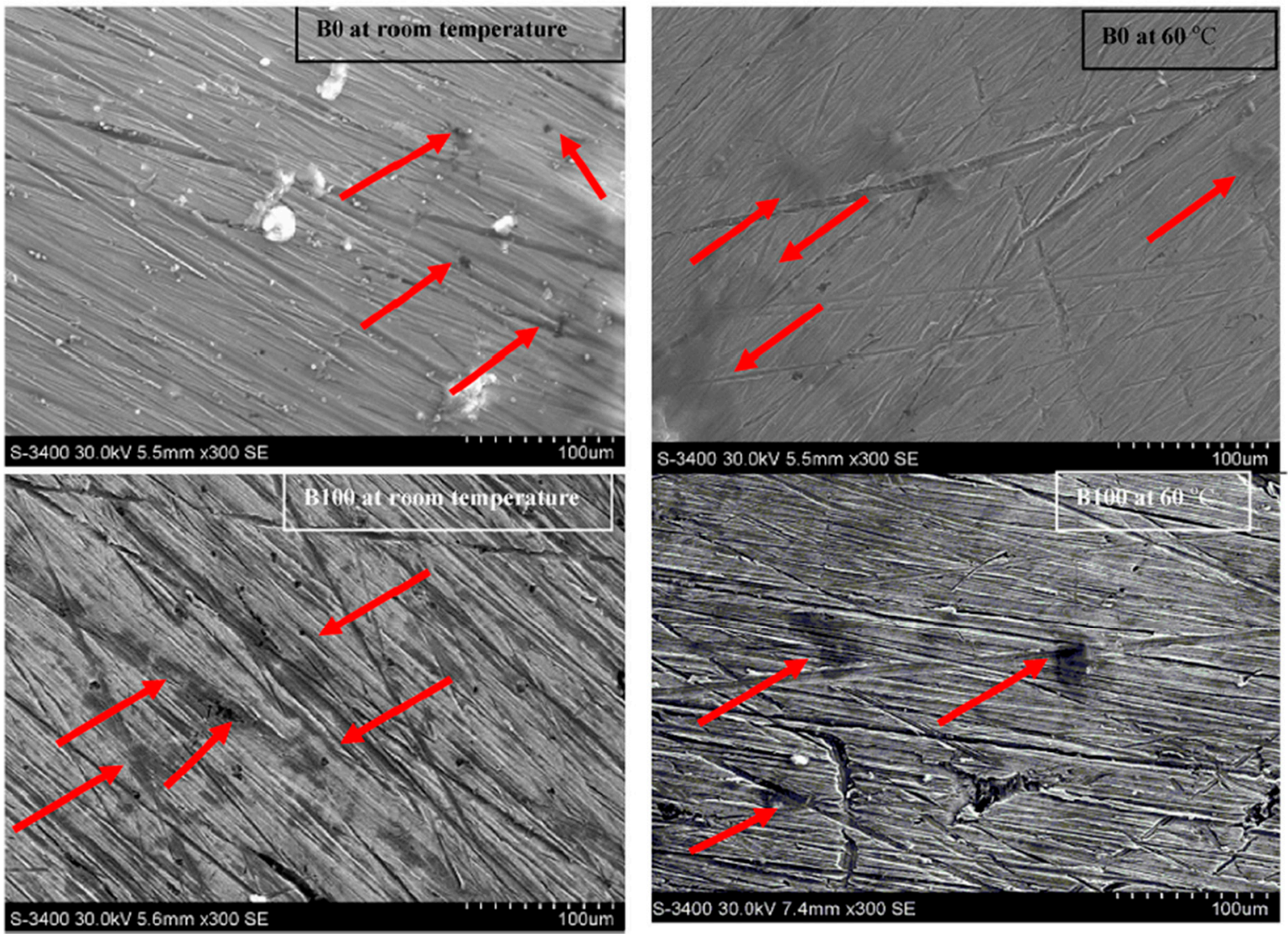

(iii)

Figure 19. SEM images of $\mathrm{Al}$ (i), $\mathrm{Cu}$ (ii) and MCS (iii) after immersions in diesel and biodiesel for $3000 \mathrm{~h}$ [74].

\section{Application of Corrosion Inhibitors to Protect Corrosion}

Jakeria et al. [69] used two organic corrosion inhibitors to assess the corrosion behaviors of MS and $\mathrm{Cu}$ when exposed to palm biodiesel. The inhibitors which were used include adenine and benzotriazole. Static immersion tests were performed at RT for 60 days. The $\mathrm{CR}$ of $\mathrm{Cu}$ had been reduced effectively by using benzotriazole than that of MS after 60 days. The CR of $\mathrm{Cu}$ dropped from 0.7495 to $0.0229 \mathrm{mg} / \mathrm{cm}^{2}$. In the presence of adenine, the CR of $\mathrm{Cu}$ reduced from 0.7495 to $0.2512 \mathrm{mg} / \mathrm{cm}^{2}$. There was little effect of adenine found in the reduction in the CR of MS. Therefore, it was concluded that benzotriazole provides better corrosion resistance as compared to adenine.

\section{Future Recommendations}

The biodiesel obtained from different sources has proved to be corrosive among the engine parts. Most of the studies to assess the corrosion rate of materials when immersed in biodiesel have been performed at higher blends of biodiesel i.e., at B50 or more. However, the usage of biodiesel along with diesel is not increased beyond B5 in most countries, and the reason behind this is the corrosiveness of biodiesel. Therefore, to enhance the usage of biodiesel in engines, the blends with percentages 10,15 or 20 should be examined so that these can be further studied and implemented to be used in diesel engines along with diesel. The higher blends always showed that the biodiesel is corrosive and hence cannot be used in diesel engines. Therefore, some systematic studies are the requirement to implement a more percentage of biodiesel in blend with diesel.

As the compatibility of biodiesel with engine parts is not good, its use in automotive engines is limited. The engine parts are made from many materials involving steel and 
its alloys, aluminum, copper, brass and some other materials. Most of the studies have shown that copper and brass are the materials that have been most affected by biodiesel in terms of corrosion. Therefore, some alternate materials such as aluminum and stainless steel should be used to make parts that were previously made from copper, as stainless steel and aluminum have proved to be the least corrosive in biodiesel.

Additionally, to avoid corrosion, the materials can be coated with some useful coatings to prevent corrosion if it is necessary to use copper and brass parts of engines. These coatings will then reduce the intensity of corrosion of materials.

Corrosion inhibitors such as adenine and benzotriazole have shown good results in reducing the corrosion intensity of materials; however, these studies were performed for a limited period and hence they can be performed for longer durations and can be used in proper fractions to reduce the corrosion of materials in biodiesel.

\section{Conclusions}

Corrosion studies of materials, when coming in contact with biodiesel, are discussed in this study and it can be concluded that:

- Copper has is most affected materials in biodiesel in terms of corrosion followed by brass-, aluminum- and steel-based alloys, respectively. Additionally, the corrosion phenomena, surface morphology, mechanisms of corrosion and products of corrosion have been presented and it can be concluded that pitting is the most common type of corrosion that occurs from the use of biodiesel.

- Most of the materials produce their respective oxides in biodiesel and because of the presence of free oxygen.

- The immersion test method is a beneficial method for corrosion rate measurement.

- The main reasons of corrosion were the presence of unsaturated fatty acids, free water content, the biodiesel feedstock and condensation water on the surface of materials.

- With corrosion, the biodiesel degrades and hence results in an increased wear rate of the engine parts in contact with the biodiesel. Therefore, it is important to minimize corrosion affects produced by the use of biodiesel in engines.

- Most of the biodiesels have shown increased corrosion of materials when the concentration of biodiesel and duration of immersion or temperature was increased.

Author Contributions: Conceptualization, A.S. and A.A.; validation, M.M.Q., S.M.A.R. and M.H.H.; formal analysis, M.J.; investigation, H.M.A.J.; data curation, A.A.; writing-original draft preparation, A.S.; writing-review and editing, M.M.Q.; visualization, M.H.H.; supervision, A.A. All authors have read and agreed to the published version of the manuscript.

Funding: This research received no external funding.

Institutional Review Board Statement: Not applicable.

Informed Consent Statement: Not applicable.

Data Availability Statement: Not applicable.

Conflicts of Interest: The authors declare no conflict of interest. 


\begin{tabular}{llll}
\multicolumn{2}{l}{ Abbreviations } \\
CR & Corrosion Rate & \multicolumn{2}{l}{ Spectroscopy } \\
\hline SS & Stainless Steel & WSOB & Waste Sunflower Oil Biodiesel \\
Mg & Magnesium & FTIR & Fourier Transform Infrared \\
MS & Mild Steel & EDS & Energy Dispersive Spectroscopy \\
SEM & Scanning Electron Microscope & RT & Room Temperature \\
XRD & X-Ray Diffraction & HT & High Temperature \\
TAN & Total Acid Number & Cu & Copper \\
OM & Optical Microscope & BS & Brass \\
XPS & X-ray Photoelectron Spectroscopy & Al & Aluminum \\
Spectroscopy & & CI & Cast Iron \\
AAS & Atomic Absorption Spectroscopy & MCS & Mild Carbon Steel
\end{tabular}

\section{References}

1. Aquino, I.P.; Hernandez, R.P.B.; Chicoma, D.L.; Pinto, H.P.F.; Aoki, I.V. Influence of light, temperature and metallic ions on biodiesel degradation and corrosiveness to copper and brass. Fuel 2012, 102, 795-807. [CrossRef]

2. McCormick, R.; Ratcliff, M.; Moens, L.; Lawrence, R. Several factors affecting the stability of biodiesel in standard accelerated tests. Fuel Process. Technol. 2007, 88, 651-657. [CrossRef]

3. Sadrolhosseini, A.R.; Moksin, M.M.; Yunus, W.M.M.; Talib, Z.A.; Abdi, M.M. Surface plasmon resonance detection of copper corrosion in biodiesel using polypyrrole-chitosan layer sensor. Opt. Rev. 2011, 18, 331-337. [CrossRef]

4. Ononiwu, I.; Adams, F.V.; Joseph, I.; Afolabi, A.S. Corrosion behaviour of mild steel in biodiesel prepared from ghee butter. In Proceedings of the World Congress on Engineering, London, UK, 1-3 July 2015.

5. Kralova, I.; Sjöblom, J. Biofuels-renewable energy sources: A review. J. Dispers. Sci. Technol. 2010, 31, 409-425. [CrossRef]

6. Kansedo, J.; Lee, K.T.; Bhatia, S. Biodiesel production from palm oil via heterogeneous transesterification. Biomass Bioenergy 2009, 33, 271-276. [CrossRef]

7. Antolın, G.; Tinaut, F.V.; Briceño, Y.; Castaño, V.; Pérez, C.; Ramírez, A.I. Optimisation of biodiesel production by sunflower oil transesterification. Bioresour. Technol. 2002, 83, 111-114. [CrossRef]

8. Qiu, F.; Li, Y.; Yang, D.; Li, X.; Sun, P. Biodiesel production from mixed soybean oil and rapeseed oil. Appl. Energy 2011, 88, 2050-2055. [CrossRef]

9. Issariyakul, T.; Kulkarni, M.G.; Meher, L.C.; Dalai, A.K.; Bakhshi, N.N. Biodiesel production from mixtures of canola oil and used cooking oil. Chem. Eng. J. 2008, 140, 77-85. [CrossRef]

10. Du, W.; Xu, Y.; Liu, D.; Zeng, J. Comparative study on lipase-catalyzed transformation of soybean oil for biodiesel production with different acyl acceptors. J. Mol. Catal. B Enzym. 2004, 30, 125-129. [CrossRef]

11. Veljković, V.B.; Biberdžić, M.O.; Banković-Ilić, I.B.; Djalović, I.G.; Tasić, M.B.; Nježić, Z.B.; Stamenković, O.S. Biodiesel production from corn oil: A review. Renew. Sustain. Energy Rev. 2018, 91, 531-548. [CrossRef]

12. Gürü, M.; Koca, A.; Özer, C.; Çınar, C.; Şahin, F. Biodiesel production from waste chicken fat based sources and evaluation with $\mathrm{Mg}$ based additive in a diesel engine. Renew. Energy 2010, 35, 637-643. [CrossRef]

13. Meher, L.; Sagar, D.V.; Naik, S. Technical aspects of biodiesel production by transesterification-A review. Renew. Sustain. Energy Rev. 2006, 10, 248-268. [CrossRef]

14. Sheehan, J.; Camobreco, V.; Duffield, J.; Graboski, M.; Shapouri, H. An Overview of Biodiesel and Petroleum Diesel Life Cycles; National Renewable Energy Lab. (NREL): Golden, CO, USA, 1998.

15. Knothe, G. Dependence of biodiesel fuel properties on the structure of fatty acid alkyl esters. Fuel Process. Technol. 2005, 86, 1059-1070. [CrossRef]

16. Espinosa, N.; Hösel, M.; Angmo, D.; Krebs, F.C. Solar cells with one-day energy payback for the factories of the future. Energy Environ. Sci. 2011, 5, 5117-5132. [CrossRef]

17. Kannan, N.; Vakeesan, D. Solar energy for future world: A review. Renew. Sustain. Energy Rev. 2016, 62, 1092-1105. [CrossRef]

18. Höök, M.; Tang, X. Depletion of fossil fuels and anthropogenic climate change-A review. Energy Policy 2013, 52, 797-809. [CrossRef]

19. Demirbas, A. Bioenergy, Global Warming, and Environmental Impacts. Energy Sources 2004, 26, 225-236. [CrossRef]

20. McGlade, C.; Ekins, P. The geographical distribution of fossil fuels unused when limiting global warming to $2{ }^{\circ} \mathrm{C}$. Nat. Cell Biol. 2015, 517, 187-190. [CrossRef] [PubMed]

21. Jaichandar, S.; Annamalai, K. The status of biodiesel as an alternative fuel for diesel engine-An Overview. J. Sustain. Energy Environ. 2011, 2, 71-75.

22. Klass, D.L. A critical assessment of renewable energy usage in the USA. Energy Policy 2003, 31, 353-367. [CrossRef]

23. Bowman, M.; Hilligoss, D.; Rasmussen, S.; Thomas, R. Biodiesel: A renewable and biodegradable fuel. Hydrocarb. Process. 2006, $85,103$. 
24. Chen, K.-S.; Lin, Y.-C.; Hsieh, L.-T.; Lin, L.-F.; Wu, C.-C. Saving energy and reducing pollution by use of emulsified palm-biodiesel blends with bio-solution additive. Energy 2010, 35, 2043-2048. [CrossRef]

25. Clark, S.J.; Wagner, L.; Schrock, M.D.; Piennaar, P.G. Methyl and ethyl soybean esters as renewable fuels for diesel engines. J. Am. Oil Chem. Soc. 1984, 61, 1632-1638. [CrossRef]

26. Tian, Y.; Zhao, L.; Meng, H.; Sun, L.; Yan, J. Estimation of un-used land potential for biofuels development in (the) People's Republic of China. Appl. Energy 2009, 86, S77-S85. [CrossRef]

27. Yan, J.; Alvfors, P.; Eidensten, L.; Svedberg, G. A future for biomass. Mech. Eng. 1997, 119, 94.

28. Ghobadian, B.; Rahimi, H.; Nikbakht, A.; Najafi, G.; Yusaf, T. Diesel engine performance and exhaust emission analysis using waste cooking biodiesel fuel with an artificial neural network. Renew. Energy 2009, 34, 976-982. [CrossRef]

29. Ramírez-Verduzco, L.F.; Rodríguez-Rodríguez, J.E.; Jaramillo-Jacob, A.D.R. Predicting cetane number, kinematic viscosity, density and higher heating value of biodiesel from its fatty acid methyl ester composition. Fuel 2012, 91, 102-111. [CrossRef]

30. Gülüm, M.; Bilgin, A. Density, flash point and heating value variations of corn oil biodiesel-diesel fuel blends. Fuel Process. Technol. 2015, 134, 456-464. [CrossRef]

31. An, H.; Yang, W.; Chou, S.; Chua, K. Combustion and emissions characteristics of diesel engine fueled by biodiesel at partial load conditions. Appl. Energy 2012, 99, 363-371. [CrossRef]

32. Muñoz, M.; Moreno, F.; Monné, C.; Morea, J.; Terradillos, J. Biodiesel improves lubricity of new low sulphur diesel fuels. Renew. Energy 2011, 36, 2918-2924. [CrossRef]

33. Fazal, M.; Haseeb, A.; Masjuki, H. Comparative corrosive characteristics of petroleum diesel and palm biodiesel for automotive materials. Fuel Process. Technol. 2010, 91, 1308-1315. [CrossRef]

34. Popovicheva, O.; Engling, G.; Lin, K.-T.; Persiantseva, N.; Timofeev, M.; Kireeva, E.D.; Völk, P.; Hubert, A.; Wachtmeister, G. Diesel/biofuel exhaust particles from modern internal combustion engines: Microstructure, composition, and hygroscopicity. Fuel 2015, 157, 232-239. [CrossRef]

35. Ghazali, W.N.M.W.; Mamat, R.; Masjuki, H.; Najafi, G. Effects of biodiesel from different feedstocks on engine performance and emissions: A review. Renew. Sustain. Energy Rev. 2015, 51, 585-602. [CrossRef]

36. Rakopoulos, C.; Rakopoulos, D.; Hountalas, D.; Giakoumis, E.; Andritsakis, E. Performance and emissions of bus engine using blends of diesel fuel with bio-diesel of sunflower or cottonseed oils derived from Greek feedstock. Fuel 2008, 87, 147-157. [CrossRef]

37. Haseeb, A.; Sia, S.; Fazal, M.; Masjuki, H. Effect of temperature on tribological properties of palm biodiesel. Energy 2010, 35, 1460-1464. [CrossRef]

38. Rashid, U.; Anwar, F.; Moser, B.R.; Knothe, G. Moringa oleifera oil: A possible source of biodiesel. Bioresour. Technol. 2008, 99, 8175-8179. [CrossRef]

39. Demirbas, A. Progress and recent trends in biofuels. Prog. Energy Combust. Sci. 2007, 33, 1-18. [CrossRef]

40. Goldemberg, J.; Guardabassi, P. Are biofuels a feasible option? Energy Policy 2009, 37, 10-14. [CrossRef]

41. Dharma, S.; Silitonga, A.; Shamsuddin, A.; Sebayang, A.H.; Milano, J.; Sebayang, R.; Sarjianto; Ibrahim, H.; Bahri, N.; Ginting, B.; et al. Properties and corrosion behaviors of mild steel in biodiesel-diesel blends. Energy Sources Part A Recover. Util. Environ. Eff. 2019, 1-13. [CrossRef]

42. Thangavelu, S.K.; Chelladorai, P.; Ani, F.N. Corrosion Behaviour of Carbon Steel in Biodiesel-Diesel-Ethanol (BDE) Fuel Blend. In Proceedings of the MATEC Web of Conferences, 2015 4th International Conference on Engineering and Innovative Materials (ICEIM 2015) EDP Sciences, Penang, Malaysia, 20 October 2015.

43. Canakci, M.; Ozsezen, A.N.; Arcaklioglu, E.; Erdil, A. Prediction of performance and exhaust emissions of a diesel engine fueled with biodiesel produced from waste frying palm oil. Expert Syst. Appl. 2009, 36, 9268-9280. [CrossRef]

44. Canakci, M.; Van Gerpen, J.H. Comparison of engine performance and emissions for petroleum diesel fuel, yellow grease biodiesel, and soybean oil biodiesel. Trans. ASAE 2003, 46, 937. [CrossRef]

45. Labeckas, G.; Slavinskas, S. The effect of rapeseed oil methyl ester on direct injection Diesel engine performance and exhaust emissions. Energy Convers. Manag. 2006, 47, 1954-1967. [CrossRef]

46. Kalligeros, S.; Zannikos, F.; Stournas, S.; Lois, E.; Anastopoulos, G.; Teas, C.; Sakellaropoulos, F. An investigation of using biodiesel/marine diesel blends on the performance of a stationary diesel engine. Biomass Bioenergy 2003, 24, 141-149. [CrossRef]

47. Dorado, M. Exhaust emissions from a Diesel engine fueled with transesterified waste olive oil . Fuel 2003, 82, 1311-1315. [CrossRef]

48. Valente, O.S.; Da Silva, M.J.; Pasa, V.M.D.; Belchior, C.R.P.; Sodré, J.R. Fuel consumption and emissions from a diesel power generator fuelled with castor oil and soybean biodiesel. Fuel 2010, 89, 3637-3642. [CrossRef]

49. Pramanik, K. Properties and use of jatropha curcas oil and diesel fuel blends in compression ignition engine. Renew. Energy 2003, 28, 239-248. [CrossRef]

50. Sureshkumar, K.; Velraj, R.; Ganesan, R. Performance and exhaust emission characteristics of a CI engine fueled with Pongamia pinnata methyl ester (PPME) and its blends with diesel. Renew. Energy 2008, 33, 2294-2302. [CrossRef]

51. Nabi, M.N.; Hoque, S.N. Biodiesel production from linseed oil and performance study of a diesel engine with diesel bio-diesel. J. Mech. Eng. 2008, 39, 40-44. [CrossRef]

52. Holser, R.A.; Harry-O'Kuru, R. Transesterified milkweed (Asclepias) seed oil as a biodiesel fuel. Fuel 2006, 85, 2106-2110. [CrossRef] 
53. Haseeb, A.; Fazal, M.; Jahirul, M.; Masjuki, H. Compatibility of automotive materials in biodiesel: A review. Fuel 2011, 90, 922-931. [CrossRef]

54. Van Wechem, G.; Beunk, G.; Van Den Elst, F.; Van Der Ploeg, A. Combustion engine with fuel injection system, and a spray valve for such an engine. U.S. Patent 4898142A, 6 February 1990.

55. Haseeb, A.S.M.A.; Masjuki, H.H.; Ann, L.J.; Fazal, M.A. Corrosion characteristics of copper and leaded bronze in palm biodiesel Fuel Process. Technol. 2010, 91, 329-334. [CrossRef]

56. Arslan, R. Emission characteristics of a diesel engine using waste cooking oil as biodiesel fuel. Afr. J. Biotechnol. 2011, 10, 3790-3794.

57. Cheng, S.; Lloyd, I.K.; Kahn, M. Modification of Surface Texture by Grinding and Polishing Lead Zirconate Titanate Ceramics. J. Am. Ceram. Soc. 1992, 75, 2293-2296. [CrossRef]

58. Kagwade, S.V.; Clayton, C.R.; Chidambaram, D.; Du, M.L.; Chiang, F.P. The Influence of Acetone Degreasing on the Corrosion Behavior of AA2024-T3. J. Electrochem. Soc. 2000, 147, 4125-4130. [CrossRef]

59. Internasional, A. ASTM G31-72: Standard Practice for Laboratory Immersion Corrosion Testing of Metals. United State. 2004. Available online: https:/ / www.astm.org/DATABASE.CART/HISTORICAL/G31-72R04.htm (accessed on 3 March 2021).

60. Ahn, S.; Choi, Y.; Kim, J.; Han, J. A study on corrosion resistance characteristics of PVD Cr-N coated steels by electrochemical method. Surf. Coat. Technol. 2002, 150, 319-326. [CrossRef]

61. Cabeza, L.F.; Roca, J.; Noguès, M.; Mehling, H.; Hiebler, S. Immersion corrosion tests on metal-salt hydrate pairs used for latent heat storage in the 48 to $58^{\circ} \mathrm{C}$ temperature range. Mater. Corros. 2002, 53, 902-907. [CrossRef]

62. Akhabue, C.; Aisien, F.; Ojo, C. The effect of Jatropha oil biodiesel on the corrosion rates of aluminium and mild carbon steel. Biofuels 2014, 5, 545-550. [CrossRef]

63. Sterpu, A.-E.; Dumitru, A.I.; Popa, M.-F. Corrosion behavior of steel in biodiesel of different origin. An. Univ. Ovidius Constanta Ser. Chim. 2012, 23, 143-148. [CrossRef]

64. Fazal, M.; Haseeb, A.; Masjuki, H. Degradation of automotive materials in palm biodiesel. Energy 2012, 40, 76-83. [CrossRef]

65. Thangavelu, S.K.; Piraiarasi, C.; Ahmed, A.; Ani, F. Corrosion Behavior of Copper in Biodiesel-Diesel-Bioethanol (BDE). Adv. Mater. Res. 2015, 1098, 44-50. [CrossRef]

66. Jin, D.; Zhou, X.; Wu, P.; Jiang, L.; Ge, H. Corrosion behavior of ASTM 1045 mild steel in palm biodiesel. Renew. Energy 2015, 81, 457-463. [CrossRef]

67. Fazal, M.; Haseeb, A.; Masjuki, H. Effect of temperature on the corrosion behavior of mild steel upon exposure to palm biodiesel. Energy 2011, 36, 3328-3334. [CrossRef]

68. Chew, K.; Haseeb, A.; Masjuki, H.; Fazal, M.; Gupta, M. Corrosion of magnesium and aluminum in palm biodiesel: A comparative evaluation. Energy 2013, 57, 478-483. [CrossRef]

69. Jakeria, M.R.; Fazal, M.A.; Haseeb, A.S.M.A. Effect of corrosion inhibitors on corrosiveness of palm biodiesel. Corros. Eng. Sci. Technol. 2015, 50, 56-62. [CrossRef]

70. Kaul, S.; Saxena, R.; Kumar, A.; Negi, M.; Bhatnagar, A.; Goyal, H.; Gupta, A. Corrosion behavior of biodiesel from seed oils of Indian origin on diesel engine parts. Fuel Process. Technol. 2007, 88, 303-307. [CrossRef]

71. Hu, E.; Xu, Y.; Hu, X.; Pan, L.; Jiang, S. Corrosion behaviors of metals in biodiesel from rapeseed oil and methanol. Renew. Energy 2012, 37, 371-378. [CrossRef]

72. Norouzi, S.; Eslami, F.; Wyszynski, M.L.; Tsolakis, A. Corrosion effects of RME in blends with ULSD on aluminium and copper. Fuel Process. Technol. 2012, 104, 204-210. [CrossRef]

73. Cursaru, D.; Mihai, S. Corrosion Behaviour of Automotive Materials in Biodiesel from Sunflower Oil. Rev. Chim. 2012, 63, 149-158.

74. Samuel, O.D.; Gulum, M. Mechanical and corrosion properties of brass exposed to waste sunflower oil biodiesel-diesel fuel blends. Chem. Eng. Commun. 2019, 206, 682-694. [CrossRef]

75. Cursaru, D.-L.; Brănoiu, G.; Ramadan, I.; Miculescu, F. Degradation of automotive materials upon exposure to sunflower biodiesel. Ind. Crop. Prod. 2014, 54, 149-158. [CrossRef]

76. Díaz-Ballote, L.; López-Sansores, J.; Maldonado-López, L.; Garfias-Mesias, L. Corrosion behavior of aluminum exposed to a biodiesel. Electrochem. Commun. 2009, 11, 41-44. [CrossRef]

77. Lu, Q.; Zhang, J.; Zhu, X. Corrosion properties of bio-oil and its emulsions with diesel. Chin. Sci. Bull. 2008, 53, 3726-3734. [CrossRef]

78. Román, A.S.; Méndez, C.M.; Ares, A.E. Corrosion Resistance of Stainless Steels in Biodiesel. In Shape Casting: 6th International Symposium; Springer: Cham, Switzerland, 2016.

79. Geller, D.P.; Adams, T.T.; Goodrum, J.W.; Pendergrass, J. Storage stability of poultry fat and diesel fuel mixtures: Specific gravity and viscosity. Fuel 2008, 87, 92-102. [CrossRef]

80. Aghbashlo, M.; Tabatabaei, M.; Khalife, E.; Najafi, B.; Mirsalim, S.M.; Gharehghani, A.; Mohammadi, P.; Dadak, A.; Shojaei, T.R.; Khounani, Z. A novel emulsion fuel containing aqueous nano cerium oxide additive in diesel-biodiesel blends to improve diesel engines performance and reduce exhaust emissions: Part II-Exergetic analysis. Fuel 2017, 205, 262-271. [CrossRef]

81. Aghbashlo, M.; Tabatabaei, M.; Mohammadi, P.; Mirzajanzadeh, M.; Ardjmand, M.; Rashidi, A. Effect of an emission-reducing soluble hybrid nanocatalyst in diesel/biodiesel blends on exergetic performance of a DI diesel engine. Renew. Energy 2016, 93, 353-368. [CrossRef] 
82. Aghbashlo, M.; Tabatabaei, M.; Mohammadi, P.; Pourvosoughi, N.; Nikbakht, A.M.; Goli, S.A.H. Improving exergetic and sustainability parameters of a DI diesel engine using polymer waste dissolved in biodiesel as a novel diesel additive. Energy Convers. Manag. 2015, 105, 328-337. [CrossRef]

83. Aghbashlo, M.; Tabatabaei, M.; Rastegari, H.; Ghaziaskar, H.S. Exergy-based sustainability analysis of acetins synthesis through continuous esterification of glycerol in acetic acid using Amberlyst@36 as catalyst. J. Clean. Prod. 2018, 183, 1265-1275. [CrossRef]

84. Ahmmad, M.S.; Haji Hassan, M.B.; Kalam, M.A. Comparative corrosion characteristics of automotive materials in Jatropha biodiesel. Int. J. Green Energy 2018, 15, 393-399. [CrossRef]

85. Aksoy, F. Alkaline catalyzed biodiesel production from safflower (Carthamus tinctorius L.) oil: Optimization of parameters and determination of fuel properties. Energy Sources Part A Recover. Util. Environ. Eff. 2016, 38, 835-841. [CrossRef]

86. Al-Dawody, M.F.; Bhatti, S. Optimization strategies to reduce the biodiesel NOx effect in diesel engine with experimental verification. Energy Convers. Manag. 2013, 68, 96-104. [CrossRef]

87. Amaya, A.; Piamba, O.; Olaya, J. Improvement of Corrosion Resistance for Gray Cast Iron in Palm Biodiesel Application Using Thermoreactive Diffusion Niobium Carbide (NbC) Coating. Coatings 2018, 8, 216. [CrossRef]

88. Amgain, K.; Subedi, B.N.; Joshi, S.; Bhattarai, J. Investigation on the effect of tinospora cordifolia plant extract as a green corrosion inhibitor to aluminum and copper in biodiesel and its blend. In Proceedings of the NIGIS* CORCON 2018, Jaipur, India, 30 September-3 October 2018. Paper No. PP19.

89. Ashraful, A.; Masjuki, H.; Kalam, M.; Rashedul, H.; Sajjad, H.; Abedin, M. Influence of anti-corrosion additive on the performance, emission and engine component wear characteristics of an IDI diesel engine fueled with palm biodiesel. Energy Convers. Manag. 2014, 87, 48-57. [CrossRef] 